\title{
WATER SCIENCE AND TECHNOLOGY BOARD ANNUAL REPORT 1988
}

Water Science and Technology Board Commission on Engineering and Technical Systems Commission on Physical Sciences, Mathematics, and Resources National Research Council

NATIONAL ACADEMY PRESJ̄

Washington, D.C. 1989 
The Water Science and Technology Board is a unit of the National Research Council, which serves as an independent adviser to the federal government on scientific and technical questions of national importance. The National Rescarch Council, jointly administered by the National Academy of Sciences, National Academy of Enginecring, and the Institute of Medicine, brings the resources of the entire scientific and tecinical community to bear on ational problems through its volunteer advisory committees.

\section{MAILING ADDRESS:}

Water Science and Technology Board

National Rescarch Council

2101 Constitution Avenue, N.W. (HA-278)

Washington, D.C. 20418

OFFICE LOCATION:

2001 Wisconsin Avenue, N.W.

Milton Harris Building, Suite 278

TELEPHONE NUMBERS:

(202) 334-3422 (Commercial)

737-3422 (FTS - Incoming)

TELECOPIER:

(202) $334-2620$

ELECTRONIC MAIL:

BITNET - USERNAME@NAS 


\section{CONTENTS}

1. WATER SCIENCE AND TECHNOLOGY BOARD OVERVIEW

2. ACTIVITIES COMPLETED IN 1988

3. CURRENT PROGRAM 8

4. NEW ACTIVITIES BEGINNING IN 1989

5. FUTURE PLANS (IN 1989 AND BEYOND) 20

APPENDIX A. PROGRAM PARTICIPANTS 25

APPENDIX B. TERMS OF REFERENCE $\quad 42$

APPENDIX C. REPORTS ISSUED BY THE WATER SCIENCE
AND TECHNOLOGY BOARD $(1983-1988)$

APPENDIX D. MEETINGS OF THE WATER SCIENCE AND
TECHNOLOGY BOARD AND ITS
SUBGROUPS DURING 1988

\section{DISCLAIMER}

This report was prepared as an account of work sponsored by an agency of the United States Government. Neither the United States Government nor any agency thereof, nor any of their employees, makes any warranty, express or implied, or assumes any legal liability or responsibility for the accuracy, completeness, or usefulness of any information, apparatus, product, or process disclosed, or represents that its use would not infringe privately owned rights. Reference herein to any specific commercial prodict, process, or service by trade name, trademark, manufacturer, or otherwise does not necessailly constitute or imply its endorsement, recom. mendation, or favoring by the United States Government or any agency thereof. The views and opinions of authors expressed herein do not necessarily state or reflect those of the United States Government or any agency thereof. 


\section{WATER SCIENCE AN TECHNOLOGY BOARD OVERVIEW}

NINETEEN EIGHTY-EIGHT was a year when water--so of ten taken for granted--made news. The drought was a water issue people could feel, and the medical wastes that washed ashore on our nation's beaches created a problem pcople saw all too vividly. It was a year that clearly illustrated the importance of water, a year that highlighted many of the challenges that water scientists and policy makers must prepare to face on a global scale.

This annual report of the Water Science and Technology Board (WSTB) summarizes the activities of the Board and its subgroups during 1988, its sixth year of existence. Included are descriptions of current and recently completed projects, new activities scheduled to begin in 1989, and plans for the ruture. The report also includes information on Board and committee memberships, program operational features, and reports produced during the past several years. This annual report is intended to provide an introduction to the WSTB and summary of its program for the year. Several hundred copics are distributed widely throughout the water community. Many of our readers are people about to become involved in WSTB activitics, either as appointed voluntecrs, recipients of advice, or sponsors of WSTB efforts. Others are individuals who know only pieces of the program but are generally interested in other aspects.

The WSTB is a dynamic forum, a mechanism by which the broad community of water science, technology, and policy professionals can help assure high quality national water programs. As such, the Board considers outreach and communications of much importance. We welcome inquirics and suggestions conccrning our activitics and will provide more detailed information on any aspect of Board projects.

The WSTB is a unit of the National Rescarch Council, the operating wing of the National Academy of Sciences and the National Academy of Enginecring, which cxist by virtuc of an 1863 act of Congress requiring the National Academy of Sciences to provide scientific ind technological assistance to the federal government upon request. While the WSTB works closely with exccutive agencics of the federal governnent in a scientific advisory capacity, it is not a part of the government. The intellectual resources and expertise available to the Board extend across many disciplines and types of organizations concerned with water and related natural resources. These resources and the Board's independence afford a unique forum for addicssing various important issucs on the nation's agenda of water resources and environmental agenda. 
The WSTB was organized in 1982 as the focal point for water-related activitics within the National Rescarch Council (NRC). It was created out of recognition of the increasing importance of water resources to our nation and the cxpcetation that a standing unit within the NRC could be a prominent and valuable resource. This expectation has proven to be correct in the Board's relatively short six-year history. As the nation--in fact, the world--begins to cope with an increasingi: complex set of scientific, technological, and policy questions involving water, the coming years promisc to be both exciting and challenging.

The Board's scope covers the traditional scientific and engineering aspects of water resources and the economic, legal, institutional, cducational, and social aspects as well. Because of its broad and diverse interests, the Board is accountable to two commissions (i.e., parent bodics) in the National

Rescarch Council: the Commission on Enginecring and Technical Systems and the Commission on Physical Sciences, Mathematics, and Resources. Indeed, when this arrangement was created in 1982, the WSTB was breaking new organizational ground in the NRC. Since then, formal corperation among its many units has become a NRC management thrust. In 1989, the Board will be undertaking new activities in cooperation with the NRC's Office of International Affairs (see page 20) and the Board on Agriculturc (page 1'7).

The WSTB gencrally meets three times each year, and its seventeenth meeting was held in December 1988. Twenty-onc voluntecrs from universitics and industry served as WSTB members during 1988, with collective interest and expertise that covered a wide range of subjects. Scveral hundred others served on study committecs, as report revicwers, as government agency representatives to the program, and in 'other resource capacitics. At WSTB mectings, ongoing projects are monitored, new initiatives are developed, and rescarch needs and other issues are considered.

In addition to these "business" aspects, mectings of the WSTB foster communication within the water resources community. Most agencies with water-rclated responsibilities have liaison representatives who actively attend and contribute at WSTB mectings. Additional communication occurs among the liaison members, who occasionally mect as a group to address WSTB-related and other matters, and through a bi-monthly WSTB NEWSLETTER, produced by the WSTB staff, and the WSTB ANNUAL REPORT. In addition, in 1988 WSTB members and staff met informally on several occasions with agency representatives and others to discuss various aspects of the program and plan activitics. In 1989 , the Board will host its fifth colloquium on emerging issucs in water science and technology and will launch a new distinguished lecture series with a similar ineme.

Studies undertaken by the WSTB can be initiated in cither of two ways. Most commonly, topics are chosen for study after a request by a government agency or other body. At times, the WSTB will initiate a proposal for a study it considers cspecially important, secking financial support from appropriatc organizations. Board members play an important leadership rolc in all WSTB studics, and they are responsible for activitics such as project development, committec nominations, and report reviews. WSTB studies, however initiated, address rescarch, science, engincering, and technology related to the development and management of water and related resources, especially in 
relation to national objectives and prioritics. Of increasing importance also is the aspect of water resources conecrned with pre-college and public education with respect to environmental sciences. One critical goal for the WSTB is to disseminate the results of its activities widely and provide a forum for the exchange of information on water science and technology issucs.

The Board's principal products are its reports (sec Appendix C). They range from "letter" reports, generally focused on particular agency programs and read by a limited, but important, audience of government managers, to major publications distributed by the thousands by the National Academy Press that address more gencral arcas of science, technology, and policy. In all cases, the reports have had and arc having important effects, and the WSTB's visibility and credibility have increased with each successive project in its six-year history.

Most WSTB reports are written by special committecs and pancls of experts (see Appendix A). These committecs are supported by a small staff which is critical to the effective and timely performance of all committec activitics. The staff helps ensure that the group's tasks are carefully formulated and clearly understood, that all NRC policies and procedures are followed, that the professional community has becn surveyed in the sclection of committce members, and that expert technical assistance and logistical support is available right through the critical Academy pecr revicw process and publication.

In 1988, financial support for the WSTB's general program and specific project activitics was provided by the U.S. Environmental Protection Agency, U.S. Geological Survey, Bureau of Reclamation, U.S. Army, Federal Emergency Management Agency, U.S. Department of Energy, National Science Foundation, National Weather Service, U.S. Nuclear Regulatory Commission, the State of California, Electric Power Research Institute, The Joyce Foundation, Mobil Corporation, and the National Rescarch Council itsclf. The total WSTB budget for 1988 totaled slightly over $\$ 1.0$ million, three times greater than in 1983 (its first full ycar of opcration). It was approximatcly 10 percent higher than in 1987. Real program growth in 1988, however, was insignificant. This is attributed mainly to the fact that 1988 was the ycar "betwecn administrations," when rederal executive agencies hesitate to undertake new policy initiatives. Interestingly, during 1988 the WSTB invested much encrgy and resources in developing several new activitics that are scheduled, or cxpected to begin in 1989, when continued program growth is anticipated.

In previous ycars, the WSTB ANNUAL REPORT has discussed the Board's newness and program growth as if these characteristics inherently provided freshness or excitement. While the program can no longer be considered "new," cach successive project provides new challenges, often in new technical and policy arcas. For example, in 1989 the WSTB will be undertaking new studics of the hydrologic functions of surface-mined sites and restoration of aquatic systcms. It will also be expanding its scope of opcrations to much of the developing world as it begins advising the U.S. Agency for International Development on issues related to soil and water conservation. No project is without some controversy and yet, upon completion, most of the Board's projects secm to have resulted in change and improvement in the relevant area(s) of water science, technology, or policy. 
Sorne of the year's highlights include progress on the Board's broad assessment of the ficld of scientific hydrology, initiation of a revicw of the proposed National Water Quality Assessment Program, initiation of a study to develop a program of coasial crosion zone managment within the National Flood Insurance Program, a workshop on long-term water quality monitoring for the U.S. Geological Survey, a colloquium concerning coastal management problems caused by the fluctuation of Great Lakes water levels, and completion of the study of scientific and regulatory aspects of ground water modeling. The WSTB's program this year seemed to have special relevance to noteworthy hydrologic events in the world and to the water issues foremost in the public's mind.

The Board is encouraged by apparent renewed interest in environmental awareness expressed not only by the new Bush Administration, but by industry, state and local gowernments, and the public. Indeed, Time Magazine's choice of Endangered Earth as Planct of the Ycar in its January 2, 1989 issuc is an indication that environmental problems have become of great prominence and that international solutions must be found. 


\section{ACTIVITIES COMPLETED IN 1988}

\section{Ground Water Models: Scientific and Regulatory Applications}

Ground water models are tools that simulate the flow and transport and environmental fate of contaminants in the soil and ground water. Models are used to understand gruund water systems and to simulate and predict the systems' behavior because the subsurface environment is not easily observed or accessible. Models are mathematical approximations of complex phenomena, or in other words, "an abstraction from and oversimplification of the real world." However, models can appear more certain and precise than they are and of ten receive unmerited credibility.

The growth in the use of ground water models in the United States results from a series of stringent and comprehensive statutes developed in the early 1970's. These include: the Comprehensive Environmental Response, Compensation, and Liability Act (CERCLA or "SUPERFUND"); the Resource Conservation and Recovery Act (RCRA); the Safe Drinking Water Act; and the National Environmental Pclicy Act (NEPA). Highly publicized pollution incidents such as the relocation of residents from the hazardous waste landfill known as Love Canal, New York, the relocation of the entire town of Times Beach, Missouri, due to soil contamination, and the potential for contamination from nuclear waste disposal sitcs, have increased the public's awareness of the importance and vulnerability of ground water supplies.

The fact that there are undeniable scientific uncertainties inherent in model prediction raises the question of how models should be used in the regulatory system. The regulatory system has grappled with the question of what level of scientific certainty is necessary in making regulatory decisions and how to balance the need to base regulatory decisions on sound science with the other mandates of the statutes involved. The U.S. Environmental Protection Agency (EPA), for example, is increasingly using ground water flow modeling for hazardous waste site investigations and appears dedicated to using models at an increasing rate.

The Committee on Ground Water Modeling Assessment (see Appendix A) was formed in June 1987 and was sharged to examine the current state of knowledge of ground water models and the role of contaminant transport models in the regulatory community. The 20 - inonth study was supported by the Electric Power Research Institute, the U.S. Nuclear Regulatory Commission, the U.S.

Environmental Protection Agency, the National Science Foundation, and the U.S. Army. 
The committee's efforts resulted in a National Academy of Sciences' report entitled, Ground Water Models: Scientific and Regulatory Applications (see Appendix C). The report (in press at the time of Annual Report preparation) of fers discussions on ground water and unsaturated flow processes, legal and regulatory perspectives on ground water flow and contaminant modeling, and several case studies focusing on the applications of models.

The report includes seven chapters: Summary of Conclusions and

Recommendations; Introduction; Modeling of Processes; Flow Processes (includiij saturated, unsaturated, and fracture flow); Transport (including conservation solutes, non-conservative solutes, and multiphase transport); Experience With Contaminant Flow Models in the Regulatory System; Issues in the Development and Use of Models; and Research Irends.

The committec stresses that properly applied ground water models are useful tools to assist in problem evaluation, design remedial strategy, conceptualize and siudy ground water flow processes, provide additional information for decision making, and recognize limitations in data and guide collection of new data. However, the committee cautions that the results of a model application are dependent on the quality of the data used as input for the model and that as models increase in complexity, more data, and a higher level and range of skill of the modelers are required.

The committee recommends that models should not replace sound scientific and engineering judgment and should be considered to be one of several methods of assessing liability in cases of ground water contamination. Furthermore, to avoid the misuse of ground water flow and contaminant models, agencies and companies should employ qualified and well-trained personnel.

Advances in ground water science and modeling over the past several decades have been many, however, major deficiencies still exist. Continued research is needed to better understand and model individual processes and reactions, to translate process level understanding to site-wide simulation capability, and to integrate the interdisciplinary technology needed to solve ground water contamination problems.

\section{Great Lakes Water Levels: Shoreline Dilemmas}

In 1986, Great Lakes water levels approached record high levels and shoreline recession rates grew noticeably in many places. A February 1987 storm exposed the linits of Chicago's well known, armored shorcline, flooding strects and buildings along the North Shore. As in prior cases of high or low water levels, political pressure for a solution became apparent in both the United States and Canada.

Against this background, the Water Science and Technology selected the subject of Great Lakes water levels for its fourth colloquium (sec Appendix A for stecring committee members). The board was intrigued by the complex and interdependent scientific and institutional issues that could be discussed involving climatology, hydrology, hydraulics, shoreline processes, lake ecology, land use planning, economics, and sociology. In particular, it seemed useful to take the opportunity to engage some 65 persons with expertise and personal irivolvement in Great Lakes issues in a detailed discussion of policy options. 
The colloquium was held in Chicago on March 17-18, 1988. The first tay was devoted to an inspection tour of the Chicago shoreline and a slide presentation on its history. The first papers presented on March 18 at the Field Museum of Natura! liistory dealt with the nature of water level fluctuations, the impacts of these fluctuations, and the range of strategies for protecting shoreline development. After this comparatively straightforward progression of ideas, interdependencies and complexities were introduced in a discussion of policy conflicts and legal and institutional issues. As an antidote to the usual tendency to invest public agencies with all decision-making power, one author spoke of the response and decision-making role of the individual stakeholders.

Two distinct but clearly related topics were addressed in panel discussions. The first dealt with global climate change and its implications for future Great Lakes water icvels and management options. The second panel provided an overview of coastal erosion control programs as they are practiced in selected Great Lakes, Atlantic Coast, and Pacific Coast states.

Spirited discussion followed each presentation, precipitated by the remarks of an invited provocateur and continued from the floor. Predictably, most controversy arose related to discussion of options for future management policy. Virtually every shade of opinion was represented, from those advocating gradual abandonement of nearly all shoreline to one participant who argued forcefully for "completing the regularirn" of the Lakes through engineering measures.

As the papers in the proceedings (see Appendix C) will attest, much is known about the causes, characteristics, and consequences of Great Lakes water level fluctuation. Nevertheless, human activitics around the lakes have evolved in a way which exposes many people and structures to a hazard of substantial proportions. Evcry indication is that the magnitude of this hazard will increase in the future.

Engineering solutions to minimize this hazard have been proposed, but never implemented. After repeated studies, the effectiveness of these measures remains controversial, and their cost-effectiveness is in doubt. Public policy toward the development and protection of shore lands appears to be at odds with the physical realities of the lakes. In fact, many of the experts involved in the colloquium argued that existing policy seems to assume the possibility, even the probability, of an engineered solution. Yet alternative policies, more reflective of the limits of technology and of sensible cost-benefit tradeoffs, face significant lcgal, institutional, political, and social constraints.

Many of these problems could be resolved, provided the need to do so is widely perceived for a sufficiently long period. In this case, however, the lakes are not cooperating. After reaching record high levels in 1986, water levels began to fall and the public sense of urgency waned soon thereafter. Many colloquium participants referred to this relationship between water levels and levels of public interests. Perhaps the greatest challenge facing the Canadian and United States governments, then, is to find a way to formulate and win acceptance for a sensible Great Lakes management policy in the absence of a water level crisis. 


\section{CURRENT PROGRAM}

In this chapter, seven projects are described. Each title represents a separate study being conducted in 1908, but not completed in 1988, by a committee organized and overseen by the Water Science and Technology Board.

\section{Assessment of Opportunities in the Hydrologic Sciences}

Water is essential to our existence and without it life on ea:th is not possible. Water is the "blood" of our planet and it circulates through the earth and air via the "hydrologic cycle"--the pathway of water as it moves in its various phases through the atmosphere, to the earth, over and through the land, and back to the atmosphere. The study of hydrology--in general, the science of water--and engincering manipulation of water has been practiced in its most primitive form for thousands of years. Water was critical to the development of civilizations, providing water for drinking, agriculture, transportation, and power.

The development of hydrology has been largely conducted by civil and agricultural engineers working to supply water and reduce natural hazards. Contemporary hydrology, however, requires a multidisciplinary approach that recognizes the land surface, atmosphere, and ground water as an interactively coupled system. This system is interactive on local, regional, and global scales and encompasses the fields of metcorology, geology, physics, chemistry, and biology. This recent hydrologic perspective reveals important deficiencies in our basic knowledge of water science.

Thus, the Water Science and Technology Board appointed the Committee on Opportunities in the Hydrologic Science (sec Appendix A) to:

1. review the current status of the hydrologic sciences and their coupling with related geosciences and biosciences;

2. identify promising new frontiers for the hydrologic sciences and opportunities to help improve water and environmental managemeni; and

3. develop an appropriate framework for hydrologic education and research.

This 2-ycar study began in late-1987 and is sponsored by internal National Research Council funds, the U.S. Geological Survey, the U.S. Army Research Office, the National Science Foundation, the National Weather Service, the National Acronautics and Space Administration, and the Mobil Corporation. 
The committee is concerned with the rescrvoirs and fluxes that comprise the global hydrologic cycle. It is focusing on continental waters and the physical, chemical, and biological processes interactive with continental waters, such as erosion, sedimentation, solute transport, and vegetation grcith. The committee is writing a report, to be completed in late-1989, that will contain seven chapters: Hydrology and Life; The Hydrologic Sciences; Critical and Emerging Areas; Scientific Issues of Data Collection, Handling, and Storage; Scientific Priorities; Education; and Resources and Strategies Necded.

The report is expected to be an important reference work on opportunities in the hydrologic sciences, help guide science and educational policy decisions, and provide a scientific framework and research agenda for scientists, educators, and students. To maintain communication with national and international scientific communities, the committce has solicited report contributions from others, presented status reports to government agency personnel and professional societies, and conducted several surveys on education, research programs, and professional profiles of hydrologists today.

\section{Irrigation-Induced Water Quality Problems}

In 1982, scientists discovered that irrigation drainage water had contaminated the ponds at California's Kesterson National Wildlife Refuge (NWR) with toxic levels of selenium, and the discovery set in motion a chain of events that is still progressing today. Scientists, policy makers, environmental groups, farmers, and various other interest groups--both from California and from around the nation--have become involved in a long process of trying to understand and solve the problem. The incident has garnered national attention and sparked public recognition that irrigation-induced water quality problems are affecting agricultural land throughout much of the West.

The Committee on Irrigation-Induced Water Quality Prollems (CIIWQP) was formed as part of this increased national awareness (see Appendix A). The committce, which was established in April 1985 and is supported by the Department of the Interior and the State of California, was originally charged to provide ongoing guidance to the San Joaquin Valley Drainage Program (S.JVDP), the multiagency team assigned to develop a research strategy and management alternatives for the drainage-related problems in the San Joaquin Valley. This task later was expanded and the committee was asked to provide assistance to the Department of the Interior's National Irrigation Water Quality Program (NIWQP), which was set up to investigate whether similar problems were occurring elsewhere in the West.

The committee is not involved in decisions relating to the actual cleanup of the Kesterson NW/R site, but is charged to provide oversight to the SJVDP as it plans strategies for dealing with similar problems elsewhere in the San Joaquin Valley. It also provides oversight to the NIWQP so the insights gained from the California experience are heeded as similar problems are addressed clsewhere. The primary formal mechanism used to convey recommendations has been through letter reports. During its 4 years of work, the committec has met 
12 times, and together with its various subcommittees, has issued 11 letter reports in response to briefings, draft documents, and other requests for assistance (see Appendix C).

During 1988, about one-third of the committee's membership changed: four members rotated off the committee and five new members were added. The committee focused in particular on the importance of institutional issues in reaching acceptable solutions to such problems, and on the importance of not narrowing the choice of alternative solutions prematt iely. Quality assurance and quality control procedures also receiyed special attention. The committec continued to stress the need to incorporate a broad ecological perspective into the decision-making prosess.

As the committec enters its last year of operation (its term will axpire in March 1990), it is publishing a report that looks brezdly at irrigation-induced water quality problems in he West. Using the sclenium contamination in California's San Joaquin Valley as a backdrop, the report argues that the crisis there should no be dismissed as an aberration because noxious trace e!ements are being concentrated by irrigation in many river basins. Thus, lcssons can be learned from the San Joaquin Valley experience that will help us study and solve future problems elsewher as they inevitably arise. In particular, the report considers the geniaral study elenents the committee fecls are necessary to incorporate into any investigation of similar environmental problems, stressing clear problem definition, systematic analysis, reliable data, and the inclusion of social, economic, and institutional considerations as well as techniral ones. The report should be valuable to anyone who must make decisions about irrigation and water management, including policy makers; federal, state, and local agency staff; resource managers; academicians; and the public. Publica:iori is cxpected by carly summer, 1989.

\section{Evaluation of the USGS National}

\section{Water Qualily Assessment Pilot Program}

In 1985, in response to con aressional interests, the U.S. Geological Survey proposed to develop and implement a national water quality assessment program. Members of the WSTB and others met with the USGS to critique their draft program plan. This meeting led to a bricf letter report submitted to USGS in 1985 concerning the utility of the information to be gathered, biological parameters, and other matters.

This initial contact with the NAWQA program piqued the interest of the Board and a colloquium was held in 1986 titled, "National Water Quality Monitoring and Assessment." The colloquium broadly considered the need for and possible implementation of a national water quality assessment and a preceedings was issued in 1987 (see Appendix C).

In 1986, the USGS initiated a pilot program with the purpose of testing the technical design they had developed and to determine the utility of data to be collected under such an assessment.

Goals of a full-scalc NAWQA program are: 
1. to provide a nationally consistent description of current water-quality conditions for a large part of the nation's water resources;

2. define long-term trends (or lack of trends) in water quality; and

3. identify, describe, and explain, as possible, the major factors that affect observed conditions and trends in water quality.

In 1087, in response to a Department of the Interior request, a WSTB committec was appointed to review and critique the technical design of the program and its execution. The committec (sce Appendix A) is also evaluating the potential usefulness of the program. The committee is expected to provide a final recommendation that will help determine whether the NAWQA program should be expanded to a full-scale program.

The first mecting of this committec was held in October 1988 with briefings on the status of the pilot program in both surface and ground water activities. Between the first meeing in October 1988 and the second meeting in February 1989, committee members visited rive of the pilot sites, including three surface water sites (Upper Illinnis River Basin, Kentucky River Basin, and Yakima River Basin) and two glound water sites (Carson Basin and Oklahoma's Garber-Wellington Aquifer). Emphasis of the discussion during these pilot visits was on the utility and design of the program.

The committee's assessment of the program is expected to be completed by April 1990.

\section{Options for Coastal Frosion Zone Management under the National Flood Insurance Program}

The National Flood Insurance Program (NFIP) was implemented in 1968. This program enables the federal government to make flood insurance available to communities who participate in the program and in return the communities enforce floodplain provisions to reduce future flood losses. Originally, the program was to handie strictly flood losses, but in 1973 as a result of the high Great Lakes water levels, with the Flood Disaster Protection Act, the statute was changed to include flood related crosion.

Although rederal insurance currently is available for flood-related crosion losses, the Federal Emergency Management Agency (FEMA) has not implemented a program of coastal crosion hazard identification nor cstablished criteria for land management by participating communities in crosion-prone areas.

The "Upton-Jones Amendment" of 1988 added a new subsection to the National Flood Insurance Act of 1968. The new Amendment applies to any structure which is covered by a contract for flood insurance under the NFIP and is along the shore of a lake or other body of water. It covers structures which are subject to imminent collapse as a result of crosion or undermining caused by waves or water levels exceeding cyclical levels, and which are condemned by local government officials. The provision provides flood insurance payments following condemnation, amounting to 40 percent of the structurc's value or the cost of demolition, whichever is less.

In 1988, the FEMA, Federal Insurance Adrinistration (FIA) requested that the NRC provide advice on appropriate crosion management strategies, and supporting 
data and analytic methods, to be administered through the NFIP. Thus, the NRC, using the resources of both the WSTB and the Marine Board, began an assessment of options for coastal crosion zone management for incorporation in to the NFIP. The scope of the study includes a review of:

1. existing and proposed NFIP legislative requirements relative to coastal erosion;

2. existing coastal crosion management prcgrams on the Great Lakes and the oceans surrounding the United States, particulairly those administered by the sta:es, that would be applicable under the NFIP,

3. technical standards, methods, and data for support of existing manasement programs potertially applicable under the NFIP; and

4. the relationship between the structurai and other nonstructural alternatives for erosion control and the land use management and zoning, approach utilized under the NFIP.

The committee charged with carrying out this study (see Appendix A) has held four full committec meetings and two panel sessions to date. The members have expertise in a variety of areas including coastal enginecring, geomorphology, hydrology, geography, coastal mapping, sediment transport, law, and land use plancing. They have produced a draft report and are now working on their conclusions and recommendations to FEMA/FIA. A final report will be delivered to FEMA in September 1989.

\section{USGS Water Resources Research}

Since 1985, the Board's Committee on USGS Water Resources Rescarch has been providing advice to and working with U.S. Gcological Survey (USGS) scientists and managers. Originally established to provide guidance rclating to the institutes and grants provisions of the Water Resources Research Act of 1984 (Public Law 98-242), the committec's activities have expanded to a much broader scope to cover both intramural and extramural research programs of the USGS and many of the agency's other program's where additional scientific perspective is ueneficial. In addition, it is within the committce's purview to assist or collaborate with the WSTB on broader issues of research in water seience and technology, when appropriate.

The ecmmittec met three times in 1988. Maj:r topics of attention include: funding aspects and focus for the extramural grants program; scientific aspects of the developing National Water Quality Assessment Program; the agency's developing program concerning climate change and hydrology; the National Water Use Information Program; and other environmental science endeavors. In addition, the committee concerns itself with management aspects of the ageney's National Resea ch Program in water resources. Such issucs as program and project review procedures and the process of new initiatives development were topics of attention in 1988. The committec also is concerned with ways to strengthen the USGS' already considerable capabilitics in environmental and hydrologic sciences. For example, it worked with the agency staff to develop plans for a new USGS/university collaborative research program. In addition to 
the three meetings of the full committee in 1988, a small subgroup of members hosted a workshop concerning the agency's long-term water quality monitoring needs. This was particularly relevant to the agency's existing national surface water qualit monitoring networks, NASQAN and Hydrologic Benchmark, as plans evolve for the new NAWQA programs.

One issue of continuing corrern to this committee since its original appointment in 1985 is the depressed state of iunding for water resources research in general. The members suspect they have observed decreasing enrollment in water resources graduate education programs and perceive somewhat less than adequate training of professional water scicntists, engineers, and managers in some cases. The committee is concerned about the eventual effect on the ability of our universities to provide competent and ample numbers of water resources professionals. This issue is being addressed partially by the Board's Committec on Opportunities in the Hydrologic Sciences. Upon completion of that project, the Board will review the situation again and if appropriate may plan further work in this area.

In December 1988, the terms of appointment for many members expired and several new members were appointed. Appendix A lists both retired members and the roster as it stands following reorganization in January.

\section{Glen Canyon Environmental Studies}

Management of water resources has becn and will remain a critical issue for the western United States. The Bureau of Reclamation was originally created to provide federal assistance in developing water resources for agriculture in the arid West and to provide economic stability in the newly annexed portion of the Nation. Subsequently, additional goals were added to the Burcau's mission, such as providing municipal water supplies and supplying energy through the operation of hydroelectric generating facilities.

New trends and changing circumstances have requireo a reevaluation of the Burcau's mission and its priorities. More attention is being given to alternative means of supplying water through improved system management and reevaluating priority of use. Conservation of water and protection of the environment have become major public concerns to be integrated into the Board's traditional missions.

In 1986, the Bureau of Reclamation, recognizing these changing circumstances, requested assistance in evaluating and interpretin? studies of the impacts on the Colorado River in the Glen and Grand Canyons due to the operation of the Glen Canyon Dam. The WSTB eagerly accepted this request since it presented a special opportunity to examinc a set of investigations desigried to evaluate the effects of storage and power dam operation on basic carth science phenomena. Furthermore, the WSTB saw an opportunity to examine the integration of science and technology with economic, political, and legal institutions, and to bring thinking from diverse disciplines to bear on procedures used to investigate large rivers.

The committec (Appendix A) produced its first report, River and Dam Management (see Appendix C) in December 1987. In this report the committec 
concluded that the Bureau of Reclamation could not make any long-term decisions concerning the management of Glen Canyon Dam based on the Glen Canyon Environmental Studies (GCES); however the studies produced some excellent information, and many research results represent new knowledge that will contribute to the information base about the Colorado River.

After this report was issued, the committee was asked to continue providing scientific advice to the researchers and to review future study plans for Phase II. In 1988 the committee issued two letter reports. The first was addressed to the GCES project manager in July 1988 and, among other things, advised that the Bureau establish an outside Science Research Advisory Group at the Department of the Interior (DOI) level to provide advice to the four DOI agencies involved in the GCES work.

The committee also recommended that some monitoring efforts be continued until a fully planned investigation could be implemented. Continued sediment data collection was recommended at six sites in the Grand Canyon to provide the maximum amount of useful information at minimal logistic cost. It was also proposed that a major commitment be made by the Burcau to establish both intensive studies and long-term monitoring of the native fish populations in the lower Colorado River below the dam.

Tracking the condition of beaches below the dam was also proposed as a simple activity that could be tied to monitoring and future investigations of the mechanisms controlling beach formation. A major recommendation was that the Burcau perform an economic analysis of the operations of Glen Canyon Dam. This analysis should evaluate both the costs of river management in terms of possible lost power revenues (owing to the possible change to a higher plant factor operation). Thus, the potential economic gains bring benefits to other user sectors, such as recreation and legal issues involving endangered species and the mission of the Grand Canyon National Park can be evaluated. The committec also urged the DOI to ensure the physical preservation of all GCES data, records, and rescarch results through publication and to create a data base management system for future retricval of this information.

In October 1988, the committec was bricfed by the GCES project manager on the status of these recommendations. The committee concluded that the Bureau's execution of its recommendation to establish a science advisory group needed further attention. In December, a short Ictter report was directed to the Secretary of the Interior explaining the committec's rationale and providing further advice.

The committec has been requested to continue providing advice on the GCES for another 18 months, through mid-1990. A new responsibility is the organization of a symposium concerning the research conducted at Glen Canyon and the impacts of large dams on the environment. The symposium will include scientific papers prepared and presented by the researchers which will be selected and evaluated by the committce. A proceedings will be published which will document several years of research in the Colorado River in Glen and Grand Canyons. Such a publication is expected to be valuable to the Bureau of Reclamation as a basis for decisions concerning future opcrations of Glen Canyon Dam, as well as to other scholars who will have access to research concerning the impacts of large dams. 


\section{Remediating Ground Water and Soil Contamination: Are Science, Policy and Public Perception Compatible?}

Each year since 1985 , the WSTB has organized and hosted a colloquium to provide a limited public forum for discussion of a current issue, identified by the Board, that might not otherwise receive adequate attention. The colloquium series is aesigned to provide opportunities for the Board and its liaison representatives to interact with the broader community of scientists and engineers who specialize in various aspects of water resources and, through publication of a report, stimulate thinking on the topic.

The Board's fourth colloquium will fozus on how science influences policy where ground water and soil contamination are concerned. Authors will present papers that discuss what the federal and state legislative bodies expect from the scientific community in terms of hazardous waste cleanup; how effective regulatory groups have been in carrying out the policies of the legislative bodics; successes and failures in hazardous waste cleanups with emphasis on technical difficulties in achieving policy goals; the role of the scientist in helping to set policy and in educating legislative bodies; cirrent practices and applications; applying new technologies; and policy improvements to encourage remediation.

This colloquium will be held in April 1989 in Washington, D.C. As with previous colloquia, a proceedings with "signed" papers and an overview by the Board will be published. The colloquium stecring committee and other principal participants are listed in Appendix $A$. 
NEW ACTIVITIES BEGINNING IN 1989

\author{
Restoration of Aquatic Systems: \\ Science. Technology and Public Policy
}

Aldo Leopold observed in 1934 that "The time has come for science to busy itself with the earth itself. The first step is to reconstruct a sample of what we had to begin with." These are the premises of a new initiative to conduct a review and evaluation of aquatic system restorations.

Over the past 15 years, attempts have been made and techniques have developed to restore degraded lakes, rivers, estuaries, and wetlands. When the scientific basis of restoration technology is overlooked, restoration attempts are often unsuccessful. Lack of understanding of the physical, biological, and chemical systems contributes to these failures. This study is timely because restoration is an integral part of continuing national cfforts to improve water quality and the ccological health of aquatic systems.

The WSTB expects to appoint a committce carly in 1989 to:

- evaluate selected restoration projects with respect to their scientific basis, performance over time, the technologies used, the monitoring effort, costs, objectives, and the degree these objectives were fulfilled, and why it was a success or failure, taking into consideration the political and regulatory aspects;

- identify common factors of successful restoration projects and, based on this review, provide a list of recommended criteria for successful restoration efforts to serve as a model for future aquatic restoration efforts;

- identify federal policy, policy conflicts, and responsible agencies that contribute substantially to the continuing degradation of lakes, rivers, and wetlands in the United States.

After a two-year evaluation, the committee will issue a final report which is expected to be a valuable reference on the subject of iquatic system restoration.

\title{
Assessment of Western Water Management
}

In the West, continued population growth and development are increasing the demand for reliable water supplies. Surface water supplics are now almost 
fully developed, excessive withdrawal of ground water is common, and the economic, political, and environmental costs of developing additional water supplies have become prohibitive as federal and popular support for water projects has diminished. As a result of a growing population, water scarcity is increasing and new uses can be met only if existing uses are reduced, made more efficient through improved technology, or diccontinued. The West is secing increased activity in water reallocation and more efficient management--shifts of water from agriculture to higher-valued uses--are already occurring. However, agriculture is still the dominant user of water in most states. In the western states, agriculture accounts for approximately 85 percent of water consumption in the region.

Water right transfers or water marketing is one mechanism for shifting water supplies from one use to another. This occurs when surface and ground water rights are openly traded from a use such as agriculture to municipal and industrial suppliers. Water rights in some areas have sold for over $\$ 5000 / a n n u a l$ acre-foot of entitlement. An unrestricted market approach, however, may infringe upon existing water rights and cause unforeseen social and economic consequences. The federal role in facilitating water transfers is crucial, but first questions of how best to accomplish such transfers, especially how to account for third-party and environmental effects, need to bc resolved. Examples of third-party concerns are impacts on Indian water rights, rural communities, instream flow, and water quality.

The Water Science and Technology. Board and the Board on Agriculture are about to initiate a study of the effects of possible changes in the use of irrigation water supplies on the economic growth and environmental quality of the western United States. The study will include:

- an assessment of western water use patterns and prospective changes in the demand for and use of water,

- an analysis of state and federal laws and administrative practices that influence and control changes in water use,

- a description of third-party and environmental effects of water rights transfers, and

- a summary of opportunities to understand third-party effects and incorporate environmental quality goals into the mechanisms established to facilitate changes in the use of water in the West.

The study will be carried out by a multidisciplinary committec of experts from fields such as law, economics, political science, environmental sciences, hydrology, water resources, and agricultural engincering. The committee will consider two working hypotheses:

1) transfers have increased in recent years and will continue to increase in the foresecable future, and

2) some proposed transfers may have social and economic consequences that are not adequately dealt with within the framework of the existing laws.

Committce mectings will include open forums and field trips, providing all major interested parties access to the committee. It is expected that the cffort will help clarify critical scientific, economic, legal, and 
institutional issues associated with water markets and, in doing so, contribute to the improvement of mechanisms for changes in the use of western irrigation watcr. The two-ycar study will result in a widely-distributed report that is cxpected to accelerate the federal government's efforts to define proper positions and roles of water markets, a responsibility that the agencies recognize but have had difficulty implementing.

\section{Assessment of Ground Water Recharge in Mined Areas}

Mining of coal and other minerals from the earth is an important industrial and economic activity in many regions of the United States. Surface mining, however, requires the removal of soil and geologic materials, resulting in great variation between the pre-and post-mining landscape. Mining can have many impacts on the cnvironment, including changes in soil and hydrologic propertics, such as rainfall-runoff-ground water recharge relationships. Alteration of the local water balance will produce changes in water table levels and stream flow. Water quality degradation also can result from mining activities.

Congress passed the Surface Mining Control and Reclamation Act of 1977 to consider and ruinim:ze such potential negative impacts. This act requires each state to develop and enforce its own Permanent Regulatory Program for surface mining. The act requires that in post-mining restcration, the ground water "recharge capacity" of mined areas be returned to pre-mining conditions. However, the act did not define what was meant by the term "recharge capacity" or give guidelines as to how it might be measured. A recent case, the Kentucky Settlement Agrecment, has raised questions about botl. the definition of the tcrm "recharge capacity" in the context of the act and what migt.t be "cost-effective" technologic: for adequate determination of the recharge capacity. Thus, the Office of Surfacc Mining (OSM) has requested assistance in interpreting the requirement of the act and cvaluating existing hydrologic technology relevant to this requirement.

The WSTB is planning to undertake an assessment of technologies of ground water recharge cvaluation. The study will be carried out by a committec of experts in hydrogcology, enginecring, hydrology, evology, soil science, and law. The committce's scope of work will include:

1) definition of the term "recharge capacity" in the context of the act and with regard to the local water balance;

2) identification of alternative approaches to estimating ground water recharge of mined areas;

3) critique of the strengths and weaknesses of existing approaches with respect to their hydrologic and statistical validity;

4) recommendations of (and comments on the technological and administrative feasibility and cost-effectiveness) and approach (or set of approaches appropriate to various hydrogeologic settings) for determining "recharge capacity" in comparable terms for pre-mining "natural" conditions and post-mining "restored" conditions;

5) identification of considerations, such as data requirements, design standards, mining methods, landscape (including "approximate original 
contours" (AOC), water quality, variation in precipitation, and soil and vegetation factors, that are relevant to the analysis of hydrologic function $r$ ' mined areas;

6) identification of any required research to strengthen the recommended approach; and

7) recommendntions of policy change, if warranted.

The one-year study will result in a published scientific and technological report that will provide OSM with guidance on addressing the issue of ground water recharge capacity within the context of the Act and the Kentucky Settlement Agreement. The report should be of value to hydrologists, hydrogeologists, and others interested in restoration of mined areas.

\section{International Soil and Water Related Activity}

In the fall of 1988, the Board began discussions with the U.S. Agency for International Development (A.I.D.) concerning a new activity that should be underway by mid-1989. This possibly long-term effort will be undertaken in collaboration with the Board on Science and Technolggy for International Development of the NRC's Office of International Affairs (BOSTID).

A.I.D. is active world-wide in developing countries in the gene:al area of soil and water science and technology. Some of the issues with which A.I.D. soil and water programs are concerned include: erosion, deforescation, salinity, water supplies, public health, water quality, impacts of potential climate change, and others. The agency is in the process of reorganizing and bringing more focus to its programs oriented to problems in these areas through establishment of a new Soil and W'ater Agricultural Collaborative Research and Development Network (SWAN).

The WSTB and BOSTID and A.I.D. are developing specific features of an advisory arrangement where a committee will provide both technical and policy advice to the SWAN "network" through senior A.I.D. staff. The committec will operate somewhat in the continuing advisory style of the WSTB's existing Committee on U.S.G.S. Water Resources Research. It would also be responsible for conducting more in-depth deliberative studies of technical topics. In addition, in the future the committce may be asked to play a role in managing a competitive research grants program in soil and water science and technology.

Initial activity of the committee is likely to be an assessment of the scientific, technological, and management needs of the network. This will involve a general review of natural resources problems in developing countries, identification of the most pressing problems, and an evaluation of A.I.D.'s capability to respond to these problems in countries where financial assistance is being considered.

This new committec will be composed of about 12 to 14 members from various soil and water related disciplines, including the social sciences. The committee will meet several times each year, including one major meeting including most "network" representatives. This project has the potential to bring the expertise of a broad community of scientists and enginecrs to bear on some of the world's major environmental problems through SWAN. 


\section{FU'TURE PLANS (IN 1989 AND BEYOND)}

\section{Emerging Technologies in Water Treatment}

Given the nation's increasingly stringent environmental standards and criteria, new demands are being imposed on water treatment and water treatment technologies. Thus the WSTB is planning a study to evaluate the current status of water treatment technologies, assess the adequacy of technological development in this sector, and consider whether this sector will be able to achieve the environmental requirements that will demanded in the future.

Water treatment, in its broadest interpretation, includes potable water treatment, municipal and industrial wastewater treatment, removal of hazardous constituents from contaminated ground water, industrial water treatment, ind treatment of wastewater streams with low concentrations of suspended solids. This is an area of special interest to the WSTB, but one not addressed explicitly in previous work. This study would evaluate the efficiency, reliability, cost-effectiveness, and ability to minimize residuals of current water treatment technologies; evaluate the historical and current adequacy of the technological development in this sector; and recommend strategies for achieving likely future requirements.

This study would consider questions such as: has the development of water treatment technologies in the United States kept pace with the requirements set to meet national environmental goals? How does the Unites States development of these technologies compare to advances in other countries? Assuming that further advances in water treatment technology will be needed, is the current U.S. approach to such development adequate for the task? Are investments in research needed? Would closer cooperation between universities and inclustry enhance the development of new technologies? What factors constrain U.S. technology development and how can they be reduced or eliminated?

\section{Wastewater Management for Urban Coastal Areas}

As is happening in many important areas of environmental protection, decision makers responsible for wastewater management in urban coastal areas are facing difficult judgments when trying to balance environmental effectiveness and economic efficiency. Some argue that current policies, while sound in spirit, limit a community's ability to solve its wastewater management problems by limiting flexibility and discouraging the latest advances in 
science and technology from being implemented. Thus the WSTB is considering conducting a study to evaluate the scientific base, environmental

effectiveness, and economic efficiency of the national policies directing occan and estuarine coastal wastewater management.

The Federal Water Pollution Control Act requires coastal communities to provide full secondary treatment for sanitary wastewaters, and it prohibits ocean disposal of sludge (a by-product of treatment) through outfall pipes. Although Section 301(h) of the 1977 Amendments to the Act allows dischargers to apply for waivers, EPA has granted few significant waivers. At the same time, the cost of providing secondary treatment is high and federal grants for building wastewater treatment plants are being phased out. In some cases, local decision makers argue that activities different from that required by Section $301(\mathrm{~h})$ would better match wastewater management technologies with available funds and environmental priorities. In other words, for example, Boston argues that in their case the large sums of money that should be spent on secondary treatment would be more effectively spent (provide greater cnvironmental uenefits) if used to address their combined sewer overflow problem. There is debate, and growing cvidence, that in some regions the coastal ocean has considerable capacity to assimilate wastes with a minimum of cnvironmental risk.

Although this study would consider examples such as the Boston, MA metropolitan area and others, its primary purpose would be to provide a generic evaluation of the sientific, technological, and economic clements that are a part of the nation's wastewater management policies for coastal areas. Whether because they have failed to modernize existing sewage systems, identified new pollution problems that require attention, or have outgrown their current systems, urban centers along the nation's coasts will increasingly need to make judgments about wastewater management. This study would help illuminate whether existing policies are flexible enough to allow efficient responses, and whether they are in concert with advances in science and technology.

\section{Climate Change and Water Resources}

At its August 1988 meeting, the WSTB took the opportunity to reflect on its program and identify several areas of potentially useful study to be pursued in the coming few years. One general area of considcrable interest, being addressed $t \mathrm{~s}$ some extent already by the existing Committce on Opportunities in the Hydrologic Sciences and the Committee on U.S.G.S. Water Resources Research, where members felt some future efforts should be focused is the general issue of climate change and water resources. Two or three study thrusts are being discussed, as described in the following paragraphs, but the focus is yet to be determined.

Hydrologic data are used to plan and operate projects for the use of water resources. Long-term records of climate, streamflow, ground water levels, and other variables are used to predict future water resource conditions and needs. Historically, it is assumed that the record of the past may reasonably be expected to be repeated in the future.

More recently, concern has been expressed over "the greenhouse effect," or "El Nino," and other phenomena to explain variability in climatic conditions 
and water supplies. Scientists who study long-term climatic indicators may not be in agreement over whether current climate, streamflow, and ground water levels represent "wet" or "dry" cycle conditions. The drought that affected much of the nation in 1988 brought an awareness of water supplies during such period compared to more "normal" conditions. Questions arc being asked as to how to plan for the future. Nineteen eighty-cight was an unusually dry year for some regions of the United States, but is this a normal condition which may be expected to continue as a result of climate change? The answer to such questions is of critical importance, but is usually unknown.

Meteorologists and climatologists cannot provide detcrministic estimates of the expected changes in environmental fluxes (radiant energy, precipitation, wind fields) at the catchment scalc of typical water resource projects, or across projects separated by distances on the order of a few hundred kilometers. There are four fundamental questions concerning climate change impacts:

1) What statistical techniques can be used to identily change, given short time series of highly variable and correlated phenomena?

2) What techniques can be used to estimate trends reliably?

3) Can trends be represented better as deterministic processes or as stochastic processes (e.g. stationary fractals)?

4) What are the magnitudes of likcly impacts on water resources, irrigated agriculture, and urban watcr supplics of any such changes in fluxes?

While there is growing acknowledgement that the mechanisms are in place that will bring about significant warming of the carth's surface, there is little agrecment as to the specific effects--particularly relating to local geographic areas. In fact, it could be years before some of these effects become defined even in broad regional terms. In the meantime decisions concerning the development and operation of water resources in the 10 to 40 year time frame must continue to be made. The Burcau of Reclamation, for example, is renegotiating long-term water contracts as original 40 year agreements mature. In addition, studies are being considered to see if some of these older projects could be redefined to better reflect today's needs and values. The alternatives that must be evaluated must reflect the potential impacts from the grecnhouse gasses. Since it is impossible to project the localized effects of global climate change other means must be developed to help anticipate the range of impacts.

A set of critcria, hopefully a simple set, should be developed that relates the parameters of temperature and rainfall to the impacts on a given river basin or project area. By identifying a set of characteristics which can be measured and/or observed and which relate the physical and cconomic condition of the basin to long term changes in temperature and rainfall, a measure of vulnerability to various levels of climate change can be developed. Hopefully this measurc would be able to detcrminc those arcas which are cspecially sensitive to climate change and in which futurc activitics should be avoided or accelerated to minimize the impacts of change. 


\section{Water Quality Criteria for Special Populations}

The age structure of the American population is changing rapidly. The number of individuals over the age of 65 is increasing at a rate of one million per year. As the age of individuals increases, the relative ability of the immune system to ward uff infectious agents decreases. For instance the leading cause of admissions to hospitals from nursing homes is infection. Advances in chemotherapy, organ transplants, and treatment of immune deficiency disease are creating an ever burgconing population that is susceptible to many disease producing agents. Thus, a significant proportion of the population, over 10 percent, is becoming increasingly susceptible to bacterial agents commonly found in water supplies. The public health significance of commonly occurring organisms to these agents is unknown. However, evidence, for cxample, primarily from Legionclloisis diagnosis at autopsy suggests that water may be one vehicle for transmitting infection to these groups. The questions are should this growing group of individuals be protected from these organisms through witer treatment by water suppliers, special home treatment, or other mechanisms, and whose responsibility is it to inform them of the potential risk? Currently, there is no information available to these groups as to the inherent health risk of drinking or bathing in existing publicly supplied water.

\section{Supplemental Irrigation}

Another area of interest to the WSTB is the use of supplemental irrigation in the East. Supplemental irrigation is increasing in humid and semi-humid areas, such as the East. The technology is easy, but these areas have a minimal institutional framework--compared to the arid West--to manage irrigation. Thus, the WSTB is considering conducting a study of the scale of supplemental irrigation and the stresses that it poses for existing resources, primarily ground water, and the possible management options available to alleviate these stresses.

\section{Techniques for Assessing Ground Water Vulnerability}

Two approaches can be used to evaluate the contamination of soil, surface waters, and ground waters. In a reactive mode, various monitoring programs--at various spatial and temporal scales--can form the basis for identifying problem areas that have become "contaminated." Reconnaissance surveys (such as NASQAN, NAWQA, EPA's National Pesticides Survey, etc.) provide a basis for regulatory actions to remedy contaminated sites and to locate the sources (nonpoint or point sources) of this contamination. This also provides a basis for various land-use management decisions. The second approach, in a proactive mode, is to identify the land areas or activities that lead to contamination. Regulatory and management options can be implemented to prevent soil and ground water contamination. This latter approach is the focus of this suggested WSTB initiative. 
A number of techniques have been developed to assess the potential for contamination (i.e., vulnerability) either at a local scale (e.g., specific site and activity) or at a regional scale (e.g., stite- and nation-wide pesticide-use policy). Use of simulation models and various empirical numerical rating techniques have been proposed for evaluating ground water vulnerability. For examp!e, the USEPA uses a numerical ranking scheme, DRASTIC, to assess the contamination potential on the basis of physiographic and hydrogeologic setting of land areas. Similar DRASTIC-like Delphi rating schemes are being developed and used by several state environmental agencies for regulation of pesticide use. Simulation models of varying complexity (e.g., PRZM or GLEAMS) are being used to assist the EPA and other agencies in making decisions on pesticide registration. The relative merits of models versus rating schemes have been debated in the literature and by the EPA in deciding registration of Aldicarb pesticide use. The Aldicarb case is seen as a template for all future decisions made by the agency on pesticide registration. In nonagriculiural applications, the questions of site-selection for land treatment or land disposal sites for hazardous wastes also require an assessment of relative vulnerability of various candidate sites.

The use of Geographic Information Systems (GIS) is becoming popular for inventorying, archiving, retrieving, and displaying spatial data needed in the above stated approaches for evaluating vulnerability. GIS coupling to numerical ratirg schemes and to simulation models allows the production of computer-generated thematic maps displaying contamination potentials or vulnerability of land areas (at county-level or higher spatial scales). However, the varying levels of data quality and scales of the spatial data bases supporting GIS introduces great uncertainty in the reliability of these vulnerability maps. Questions as to how to validate the predictions (i.e., the GIS thematic maps) through sampling or monitoring also need to be resolved.

This proposed WSTB initiative will examine the scientific basis for and the relative merits or limitations of various schemes for evaluating vulnerability of soils, surface waters, and ground waters. Recommendations will be made on the appropriateness of the schemes within the regulatory framework. Technical issues on data quality and uncertainty of vulnerability assessments will also be addressed. 


\section{APPENDIX A}

\section{WATER SCIENCE AND TECHNOLOGY BOARD \\ PROGRAM PARTICIPANTS}

\section{BOARD MEMBERS}

Michael C. Kavanaugh, Chairman James M. Montgomery Consulting Engineers

Oakland, California

John J. Boland, Past Chairman*

The Johns Hopkins University

Stephen J. Burges

Unniversity of Washington

Richard A. Conway

Union Carbide Corporation

South Charleston, West Virginia

James M. Davidson*

University of Florida

Harry L. Hamilton, Jr.*

State University of New York at Albany

James P. Heaney

University of Florida

R. Keith Higginson

Department of Water Resources

Boise, Idaho

Howard $C$, Kunreuther

University of Pennsylvania

Lester B. Lave*

Carnegie-Mellon Unversity

Luna B. Leopold

University of California at Berkeley

*Term ended June 30,1988
G. Richard Marzolf

Murray State University

Robert R. Meglen

University of Colorado at Denver

James W. Mereer

GcoTrans, Inc.

Herndon, Virginia

Betty H. Olson

University of California

at Irvine

P. Suresh Chandra Rao

University of Florida

Gordon G. Robeck

Water Consultant

Laguna Hills, California

Patricia Rosenfield

The Carnegie Corporation of

New York

A. Dan Tarlock

Chirago Kent College of Law

Jarnes $R$. Wallis

IBM Watson Research Center

Yorktown Hcights, NY

Edith Brown Weiss*

Georgetown University Law Center 
Staff

Professional

Stephen D. Parker, Director

Sheila D. David, Staff Officer

Chris Elfring, Staff Officer

Wendy L. Melgin, Staff Officer

Secretarial

Jeanne Aquilino, Administrative Assistant

Renee Hawkins, Senior Secretary

Anita Hall, Scnior Secretary 
$-27-$

\section{FEDERAL AGENCY LIAISON REPRESENTATIVES}

William S. Bivins

Federal Fmergency Management Agency

Ralph Brooks

Tennessee Valley Authority

Bevan W. Brown

Tennessee Valley Authority

Edward Bryan

National Science Foundation

Donald L. Chery, Jr.

U.S. Nuclear Regulatory Commission

Philip Cohen

U.S. Geological Survey

Stephen R. Cordle

U.S. Environmental Protection Agency

James R. Hanchey

U.S. Army Corps of Engineers

Robert Hirsch

U.S. Geological Survey

Ron Hoffer

U.S. Environmental Protection Agency

Robert E. Murphy

National Acronautics anu Space Administration
Edgar H. Nelson

Soil Conservation Service-USDA

Frank Osterhoudt

U.S. Department of the Interior

Brent Paul

Bureau of Reclamation

William Roper

U.S. Army Corps of Engineers

John Schaake

National Weather Service/NOAA

Larry J. Schmidt

U.S. Department of Agriculture-

Forest Service

Frank H. Thomas

Federal Emergency and Management Agency

Diane E. Wickland

National Acronautics and Space Administration

Frank J. Wobber

U.S. Department of Energy

Arthur Zeizel

Federal Emergency and Management Agency 
G. Richard Marzolf, Chairman

Murray State University

David Dawdy

Consulting Hydrologist

San Francisco, California

William Graf

Arizona State University

W. Michael Hanemann

Berkeley, California

Trevor C. Hughes

Utah State University

William M. Lewis, Jr.

University of Colorado at Boulder

Duncan T. Patten

Arizona State University

A. Dan Tarlock

Chicago Kent College of Law

U.S. Department of the Interior Project Officer

David Wegner

U.S. Burcau of Reclamation 


\section{COLLOQUIUM ON}

GREAT LAKES WATER LEVELS: SHORELINE DILEMMAS

WSTB Steering Committee

John J. Boland, Chairman

The Johns Hopkins University

Lee Botts

Department of Consumer Services

Chicago, Illinois

William Cooper

Michigan State University

Kenneth W. Potter

University of Wisconsin-Madison

Edith Brown Weiss

Georgetown University Law Center

$$
\text { Principal Authors }
$$

Frank Horvath

Michigan Department of Natural Resources

Orrin H. Pilkey, Jr.

Duke University

Clancy Philipsborn

The Mitigation Assistance Corporation

Boulder, Colorado

Frank H. Quinn

National Oceanic and Atmospheric Administration
A. Dan Tariock
Chicago Kent College Law School
William L. Wood
Purdue University 


\section{COMMITTEE ON U.S.G.S WATER RESQURCES RESEARCH}

Walter R. Lynn, Chairman

Cornell University

Bctty H. Olson, Past Chair*

University of California at Irvine

Edward J. Bouwer

Johns Hopkins University

Thomas Dunne

University of Washington

Robert A. Goldstein

Electric Pewer Research Institute

Palo Alto, California

Marjoric M. Holland

Ecological Socicty of Amcrica

Washington, D.C.

Philip C. Kearncy

Agriculture Research Center

Beltsville, Maryland

Oric Loucks*

Holcomb Research Institute

Butler University

Shlomo P. Neuman

University of Arizona
Donald R. Nielsen*

University of California at Davis

George F. Pinder*

Princeton University

Kenneth W. Potter

University of Wisconsin at Madison

Eugene M. Rasmusson

University of Maryland

Clifford S. Russell

Vanderbilt University

Philip Singer

University of North Carolina

Hugo F. Thomas

State Geologist of Connecticut

Patricia Rosenficld

(ex officio, WSTB)

The Carnegie Corporation of New York

\section{U.S. Geological Survey \\ Program Officer}

Marshall E. Moss

*Term ended in December 1988 


\title{
COMMITTEE ON GROUND WATER MODELING ASSESSMENT
}

Frank W. Schwartz, Chairman

Ohio State University

Charles B. Andrews

S.S. Papadopulos \& Associates, Inc.

Rockville, Maryland

David L. Freyberg

Stanford University

Charles T. Kincaid

Battelle, Pacific Northwest Laboratory

Richland, Washington

Leonard F. Konikow

U.S. Geological Survey

Reston, Virginia

Chester R. McKee

In Situ, Inc.

Laramie, Wyoming

Dennis B. McLaughlin

Massachusetts Institute of Technology
James W. Mercer

GeoTrans, Inc.

Herndon, Virginia

Ellen J. Quinn

Northeast Utilities

Hartford, Connecticut

P. Suresh Chandra Rao

University of Florida

Bruce E. Rittman

University of Illinois at

Urbana, Champaign

Donald D. Runnells

University of Colorado

Paul K.M. van der Heijde Holcomb Research Institute Butler University

William J. Walsh

Pepper, Hamilton, and Scheetz

Washington, D.C.

\author{
Agency Project Orficers \\ Donald L. Chery, Jr. \\ U.S. Nuclcar Reguiatory Commission \\ Steve Cordle \\ U.S. Environmental Protection Agency \\ Ira May \\ U.S. Army \\ Ishwar P. Murarka \\ Electric Power Research Institute
}




\section{COMMITTEE ON OPPORTUNITIES IN THE HYDROLOGIC SCIENCES}

Peter S. Eagleson, Chairman

Massachusetts Institute of

Technology

Wilfried H. Brutsaert

Cornell University

Samucl C. Colbeck

U.S. Army Cold Regions Research and Engincering Laboratory

Hanover, New Hampshire

Kenneth W. Cummins

University of Maryland at Frostburg

Jeff Dozier

University of California at

Santa Barbara

Thomas Dunne

University of Washington

John M. Edmond

Massachusetts Institute of

Technnlogy

Vijay K. Gupta

University of Mississippi

Gordon C. Jacoby

Lamont-Doherty Geological

Observatory

Palisades, New York

James O. Leckic

Stanford University

Syukuro Manabe

Princeton University
Sharon E. Nicholson

Florida State University

Donald R. Nielsen

University of California at Davis

Ignacio Rodriguez-Iturbe

Instituto Internacional de

Estudios Avanzados

Caracas, Venezucla

Jacob Rubin

U.S. Geological Survey

Menlo Park, California

J. Leslic Smith

University of British Columbia

Garrison Sposito

University of California at

Berkeley

Wayne T. Swank

Coweeta Hydrologic Laboratory, USDA, Otto, North Carolina

Edward J. Zipser

National Center for Atmospheric Rescarch

Boulder, Colorado

Stephen Burges (ex officio, WSTB)

University of Washington

\section{Agency Project Officers}

John Maccini

National Science Foundation

Steven J. Mock

U.S. Army

Marshall E. Moss

U.S. Geological Survey
Robert E. Murphy and Ghassem

Asrar, National Aeronautics and Space Administration

John Schaake

National Weather Service 
$-33-$

\section{COMMITTEE ON IRRIGATION-INDUCED WATER QUALITY PROBLEMS (CIIWQP)}

Jan van Schilfgaarde, Chairman

Agricultural Research Service

Fort Collins, Colorado

Ernest E. Angino

University of Kansas

Margriet F. Caswell

University of California at

Santa Barbara

Edwin H. Clark II

The Conservation Foundation

Washington, D.C.

Charles T. DuMars

University of New Mexico

Wilford R. Gardner

University of California at Berkeley

Rolf Hartung

University of Michigan

Charles D. C. Howard

Charles Howard and Associates, Ltd.

Victoria, British Columbia
L. Douglas James

Utah State University

William M. Lewis, Jr.

University of Colorado at Boulder

Robert R. Meglen

University of Colorado at Denver

Ishwar P. Murarka

Electric Power Research Institute

Palo Alto, California

Albert L. Page

University of California at

Riverside

Merilyn B. Reeves

Leaguc of Women Voters

Amity, Oregon

Danicl Willard

Indiana University

Gordon Robeck (ex officio, WSTB)

Water Consultant

Laguna Hills, California

U.S. Department of the Interior Project Officers

Jonathon Deason

National Irrigation Drainage Program

Coordinator, Washington, D.C.

Edgar Imhoff

San Joaquin Valley Drainage Program Manager

Sacramento, California 


\section{CIIWQP SUBCOMMITTEE ON DATA MANAGEMENT}

Margariet F. Caswell

University of California at Santa Barbara

Edwin H. Clark II

The Conservation Foundation

Washington, D.C.

Wilford R. Gardner

University of California at Berkeley

Robert R. Meglen

University of Colorado at Denver

\section{CIIWOP SUBCOMMITTEE ON ECONOMICS AND POLICY}

Margriet F. Caswell, Chairman

University of California at

Santa Barbara

Edwin H. Clark II

The Conservation Foundation

Washington, D.C.

Charles T. DuMars

University of New Mexico

Frank Gregg

University of Arizona

Charles W. Howe

University of Colorado at Boulder

Merilyn B. Recves

Amity, Orcgon

Warren Viessman

University of Florida

Evan C. Vlachos

Colorado State University 
$-35-$

\section{CIIWQP SUBCOMMITTEE ON PUBLIC HEALTH}

Edwin H. Clark II, Chairman

The Conservation Foundation

Washington, D.C.

Larry J. Gordon

New Mexico Health and Environment Department

Santa Fe, New Mexico

Rolf Hartunz

University of Michigan

Matthew P. Longnecker

Harvard School of Public Health

Betty H. Olson

University of California at Irvine

CIIWOP SUBCOMMITTEE ON QUALITY ASSURANCE/OUALITY CONTROL

Robert R. Meglen, Chairman

University of Colorado at Denver

Ernest E. Angino

University of Kansas

J. Phyllis Fox

J. Phyllis Fox Consulting Services

Berkeley, California

Susan Jo Keith

City Managers Orfice

Phoenix, Arizona 
$-36$.

\section{CIIWQP SUBCOMMITTEE ON SYST UUS ANALYSIS}

Wilford R. Gardner, Chairman

University of California at Berkeley

Margrict F. Caswcll

University of California at Santa Barbara

Charles D. D. Howard

Charles Howard and Associates, Ltd.

Victoria, B. C.

Gerald T. Orlob

University of California at Davis

CIIWQP SUBCOMMITTEE ON TREATMENT TECHNOLOGIES

Georges Belfort

Renssclacr Polytechnic Institute

Isadore Nusbaum

Consulting Enginecr

San Dicgo, California

Vernon L. Snocyink

University of Illinois 


\section{COMMITTEE ON COASTAL EROSION ZONE MANAGEMENT}

William L. Wood, Chairman

Purdue University

Robert G. Dean

University of Florida

Martin Jannereth

Michigan Department of Natural

Resources

Lansing, Michigan

Judith T. Kildow

Massachusetts Institute of Technology

Stephen P. Leatherman

University of Maryland
Bernard LeMehaute

Miami, Florida

David Owens

North Carolina Division of

Coastal Management

Raleigh, North Carolina

Rutherford H. Platt

University of Massachusetts

Robert L. Wiegel

University of California at Berkeley

\section{Consultant}

Geraldine Bachman

Marsolon Associates

Annapolis, Maryland

\section{Federal Emergency Management Agency Project Officer}

Michacl Buckley

Washington, D.C.

\section{Liaison Representatives}

Kathryn Cousins

National Occanic and Atmospheric

Administration

Washington, D.C.

Todd L. Walton, Jr.

Coastal Engincering Research Center

Vicksburg, Mississippi

Jeff Williams

U.S. Geological Survey

Reston, Virginia 
Richard S. Engelbrecht, Chairman University of Illinois at Urbana-Champaign

Keith C. Bishop, III

Chevron U.S.A., Inc.

San Francisco, California

Sandra L. Blackstone

University of Denver College of Law

Michacl E. C inpana

University of California at Santa Cruz

Margaret Conditt

Proctcr \& Gamble

Cincinnati, Ohio

Robert C. Cooper

University of California at

Berkeley

David L. Freyberg

Stanford University

\author{
James Geraghty \\ Geraghty \& Miller, Inc. \\ Tampa, Florida \\ James P. Heaney \\ (ex officio, WSTB) \\ University of Florida \\ Judy L. Meyer \\ University of Georgia \\ Donald J. O'Connor \\ HydroQual, Inc. \\ Mahwah, New Jersey \\ Kenneth W. Potter, (ex officio, \\ Committee on U.S.G.S. Water \\ Resources Research) \\ Susan Stafford \\ Oregon State University \\ Carol H. Tate \\ James M. Montgomery Consulting \\ Engincers, Inc.
}

U.S. Geological Survey Program Officer

Verne R. Schneider

Acting Assistant Chicf Hydrologist

for Program Coordination and

Technical Support 


\section{COLLOQUIUM ON}

REMEDIATING GROUND WATER AND SOIL CONTAMINATION: ARE SCIENCE, POLICY AND PUBLIC PERCEPTION COMPATIBLE?

\section{WSTB Stecring Committee}

Richard A. Conway, Chairman Union Carbide Ccrporation South Charleston, West Virginia

Stephen Cordle

U. S. Environmental Protection Agency

James W. Mercer

GeoTrans, Inc.

Herndon, Virginia
David W. Miller Geraghty \& Miller, Inc. Plainview, New York

P. Suresh Chandra Rao University of Florida

Principal Authors

Clen D. Anderson

Environmental Law Institute

Washington, D.C.

Larry Canter

Environmental \& Ground Water

Institute

Norman, Oklahoma

Douglas Downey

Panama City, Florida

Robert Harris

ENVIRON, Inc.

Princeton, New Jersey

Douglas Mackay

University of California at Los Angeles

Perry McCarthy

Stanford University

Glenn Paulson

Center for Hazardous Waste

Management

Chicago, Illinois
Rena Steinzor

Spicgel and McDiarmid

Washington, D.C.

William A. Wallace

$\mathrm{CH}_{2} \mathrm{M}$ - Hill

Bellvue, Washington

William Walsh

Pepper, Hamilton, anc Scheetz

Washington, D.C.

Stcphen Wassersug

U.S. Environmental Protection

Agency

Philadelphia, Pennsylvania

Marcia E. Williams

Browning-Ferris Industries

Washington, D.C. 


\section{COMMISSION ON ENGINEERING AND TECHNICAL SYSTEMS}

Arden L. Bement, Jr., Chairman

TRW, Inc.

Cleveland, Ohio

John A. Armstrong

IBM Corporation

Yorktown Heights, New York

Norman H. Brooks*

California Institute of Technology

Pasadena, California

Dennis Chamot

Department for Professional

Employees, AFL-CIO

Washington, D.C.

Floyd L. Culler, Jr.

Electric Power Research Institute

Palo Alto, California

Danicl B. DeBra

Stanford University

Richard D. Delauer

The Orion Group

Arlington, Virginia

Robert R. Everett

The MITRE Corporation

Bedford, Massachusetts

Kent F. Hansen

Massachusetts Institute of

Technology

*WSTB Liaison
Elvin R. Heiberg

Rollins Field Services, Inc.

Wilmington, Delaware

William G. Howard, Jr.

National Academy of Engineering

Richard C. Messinger

Cincinnati Milacron, Inc.

Cincinnati, Ohio

Irene C. Peden

University of Washington

Eberhardt Rechtin

University of Southern California

Gregory E. Stillman

University of Illinois

Charles F. Tiffany

Bocing Military Airplane Company

Centerville, Ohio

Paul E. Torgersen

Virginia Polytechnic Institute and State University

John B. Wachtman, Jr.

Rutgers University

David L. Bodde, Commission

Exccutive Director 
Norman Hackerman, Chairman

Robcrt A. Welch Foundation

Houston, Texas

George F. Carricr

Harvard University

Herbert D. Doan

The Dow Chemical Company (retired)

Midland, Michigan

Peter S. Eagleson*

Massachusetts Institute of Technology

Dcan E. Eastman

IBM T. J. Watson Research Center

Yorktown Heights, New York

Marye Anne Fox

University of Texas

Gerhart Friedlander

Brookhaven National Laboratory

Uiton, Long Island, New York

Lawrence W. Funkhouser

Chevron Corporation (retired)

Atherton, California

Phillip A. Griffiths

Duke University

Christopher F. Mckee

University of California at Berkeley

Jack E. Oliver

Cornell University

Jeremiah P. Ostricker

Princeton University Observatory

*member, WSTB oversight group
Frank L. Parker

Vanderbilt University

Denis J. Prager*

MacArthur Foundation

Chicago, Illinois

David M. Raup

University of Chicago

Richard J. Reed*

University of Washington

Roy F. Schwitters

Harvard University

Robert E. Sievers*

University of Colorado, Boulder

Leon T. Silver

California Institute of Technology

Larry L. Smarr

University of Illinois, Champaign

Edward C. Stonc, Jr.

California Institute of Technology

Karl K. Turekian*

Yalc University

Raphael G. Kasper, Commission Executive Director 


\section{APPENDIX B}

TERMS OF REFERENCE

\section{WATER SCIENCE AND TECHNOLOCY BOARD \\ (Adopted November 29, 1982)}

\section{Introduction and Purposes}

The Water Science and Technology Board (WSTB) was established in the National Research Council to provide a singlc focal point for studies related to water resources accomplished under the aegis of the National Academy of Sciences and the National Academy of Engineering. The Board's objective is to improve the scientific and technological basis for resolving important questions and issues associated with the efficient management and use of water resources.

In carrying out its responsibilities and to serve the national interest, the Board responds to requests for evaluations and advice concerning specific and gencric issues in water resources; influences action by initiating studies of issues that merit consideration by public agencies and others; identifies issues and topics of rescarch related to water resources; and cooperates with other units of the National Research Council and groups with mutual interests outside the National Rescarch Council.

The Board's scope covers the traditional scientific and eng neering aspects of water resources and the economic, institutional, legal, educational, and social aspects, as well.

\section{Arcas of Interest}

To pursue its objectives, the Board is concerned with:

- Basic hydrologic and related sciences and their applications in water resource systems, including analyses of ground water movement and the hydrologic cycle, measurement of water quantity and quality, data analysis, and forccasting.

- Planning, analysis, and operation of water systems, including resource management, water quality and quantity for all uses, public health and environmental protection, aquifer and watershed protection and management, cconomic analysis, design standards, modeling methods, risk assessment, system analysis techniques, and management systems. 
- Nonstructural water resources issues, such as floodplain management, supply-demand relationships, water reallocation and reuse, effects of human activities on water resources, legal-institutional issues, ecosystem effects, and cultural and aesthetic values.

- Structural and traditional enginecring aspects of water projects, such as dams, levees, renovation-retrofit technologies, and treatment processes.

- The health and vitality of the nation's water-related science and cngineering establishment, including its educational aspects.

\section{General Activities}

The Board strives to accomplish its purposes through the following means:

1) Responding to specific requests by government agencies and others;

2) Reviewing and evaluating water-related researcit and scientific, engineering, and technological developments;

3) Initiating investigations of issues considered to be appropriate by the Board, its parent Commissions, and the Governing Board of the National Research Council;

4) Reviewing research and the state-of-the art in science, engineering, and technology related to the development and management of water and related resources, especially in relation to national objectives and priorities;

5) Projecting future needs for and capabilities of multi-disciplinary water-related research and education in the sciences, engineering, and technology;

6) Disseminating the results of its studies, serving as a repository of scientific and engineering knowledge, and providing a forum for the exchange of information on water science and technology;

7) Fostering communication among members of the professional community in the United States on national and international water resources issues; and

8) Articulating water-related educational issues, including undergraduate, postgraduate, continuing education, and public-education programs and the related needs for equipment and facilities.

\section{Organization and Management}

Governance and Relationship with Parent Bodies

The Board, although responsible for its own immediate governance, is accountable to and supported by two Commissions of the National Research Council--the Commission on Enginecring and Technical Systems (CETS) and the Commission on Physical Sciences, Mathematics, and Resources (CPSMR). CETS is primarily concerned with the development and application of engineering disciplines to technological systems and their relationship to societal problems, while CPSMR is primarily concerned with basic sciences and their relation to resource identification and development and environmental management. For each of its specific technical, project, or administrative activities, the Board or 
its study groups will be responsible to and supported by either CETS or CPSMR.

The Board may undertake activities related to its mission such as conferences, seminars, and mectings. It may collaborate with professional associations and other groups as may be necessary to fulfill its goals.

The Board may recornmend to the Chairman of the National Research Council and to the Commissions such changes in the purposes, responsibilities, size, and fuactions of the Board as it belicves desirable.

\section{Board Membership}

To meet its broad need for expertise, the Board consists of not fewer than 15 and not more than 18 members in addition to its Chairman. Members are chosen for their background and experience as well as for their familiarity with appropriate scientific, technological, and policy issucs. While serving on the Board, each member, insofar as possible, participates in at least one study conducted under the auspices of the Board.

Terms of appointment are normally for three years. Members are not eligible for more than two consecutive three-ycar terms. The Board Chairman is appointed by the Chairman of the National Research Council for a period not to exceed threc years. The Board nominates individuals for its own continuing membership.

When appropriate, the Board may invite federal agencies and organizations to nominate individuals to serve as non-voting liaison representatives to the Board.

\section{Study Group Activitics}

The principal operating units of the Board are its separatcly appointed and individually mandated study groups. The Board, assisted by 'ts staff, manages the activities of these units.

The Board exercises its oversight responsibility for ongoing studics by receiving reports from the chairpersons or staff and meeting with them as it decms appropriatc.

The Board originates or revicws and approves nominations for membership on the study group committecs anc transmits its recommendations to the appropriate Commission.

The Board Chairman, with the approval of the Chairman of the appropriate Commission and the Chairman of the National Rescarch Council, appoints chairmen and members of committecs of the Board.

In recommending nominations for its committecs, the Board secks advice from both within and outside the National Rescarch Council. Normally, members of committecs or pancls serve for the duration of a given study. 
Report Review

The Board reviews all reports that develop from its program in accordance with procedures and requirements established by the appropriate Commission and by the Report Review Committec of the National Research Council.

Board Meetings

The Board normally meets three times cach year, twice at the NRC headquarters in Washington, D.C., and once elsewhere in the United States. Additional meetings are held as the Board deems necessary to carry out its responsibilities for planning, oversight, and review including, but not limited to, review and assessment of current activities; consideration and approval of new projects, proposals, and proposed memberships; :echnical and programmatic briefings; and discussions with government decision-making and policy personnel.

Program Planning

The Board, with the aid of WSTB staff, annually prepares a general plan of its proposed program of activities and projects for submission to the two Commissions, accompanied by a request for authorization to receive outside funds for the support of these activities. The Board prepares reports on its activities as may be requested or required by the Commissions or the Governing Board of the National Rescarch Council.

The Board Chairman and Staff Director present the Board's program plan and budget to the Commissions. New projects, approved by the Board, that do not appear in the approved plan and authorized budget are brought to the appropriate Commission for action. The Chairman and Director also report periodically to the Commissions on any issues and problems of particular concern to the Board and any issues of broader scope that may require a response of the National Rescarch Council.

The Board formulates programs and requests funds in support of undertakings deemed to be logical, appropriate extensions of its approved program plan, subject to appropriatc approvals.

The Board reviews all proposals for new activitics that require the use of outside funds. Proposals must be approved by the Board before a request for authorization to receive funds is submitted to the appropriate Commission.

Proposed projects are evaluated by the Board according to the following criteria: (a) the importance of the issue to the nation relative to its water necds; (b) the availability of expert volunteers who can ensure that the Board's contribution will be appropriate, effective, and timcly; (c) the relevance of the work to the Board's areas of interest and competence, and (d) the involvement of policymakers of sufficicnt statuie to ensure that the Board's response will have a significant impact. 
Staff

The senior staff officer of the Board is its Director who is responsible to the Chairman for the general management of the Board's program and to the executive Directors of CETS and CPSMR. The Director has the authority to hire additional staff members and or consultants necessary to assist in the overall management of the Board's program, subject to the constraints and approvals of National Research Council policies and the administrative budget of the Board.

\section{Expenses}

Expenses of the Board and its study groups, including support of its staff and meetings, are ordinarily financed by grants or contract funds. 


\section{APPENDIX C}

\section{REPORTS ISSUED BY THE WATER SCIENCE AND TECHNOLOGY BOARD (1983-1988)}

\section{Ground Water Models: Scientific and Regulatory Applications}

$1989,300 \mathrm{pp} .(\mathrm{W} 89-2)$

Regulatory agencies increasingly rely on ground water modeling applications to solve and predict ground water contamination problems and to assess liability for specific contamination cases. Uncertainty about the extent to which models can and should be used is also increasing and a better awareness of the adequacy and limitations of models is necessary.

Ground Water Models: Scientific and Regulatory Applications addresses the use of ground water flow and contaminant transport modeling in the regulatory process. The report discusses the scientific bases upon which existing models are founded, the philosophies and approaches routinely used in the application of models to decision making for regulatory purposes, and guidelines conccrning how models should be developed and applied in the regulatory process so that their utility and credibility are enhanced.

The study committee was chaired by Frank W. Schwartz, Ohio State University. The report is available for $\$ 25.00$ from the National Academy Press, 2101 Constitution Avenue, N.W., Washington, D.C. 20418. (Report price and length are estimated, because at the time of the Annual Report publication, Ground Water Models: Scientific and Regulatory Applications was being prepared for publication.)

\section{Great Lakes Water Levels: Shoreline Dilemmas}

1989,149 pp. (W89-1)

This is the rourth report from the WSTB scries of colloquia on emerging issues in water science and technology. The colloquium was held in Chicago, Illinois on March 17-18, 1988 and addressed hydrometcorological, enginecring, and land management and policy issues related to fluctuations in Great Lakes water levels. The Board felt that this topic was of importance as the possibilities of a rising sea level and the impacts of climate change on hydrology are considered. 
Six formal papers were presented by recognized experts concerning aspects of lake level fluctuations, shorcline impacts of water level changes, alternative solution strategies, policy conflicts in existing laws, multi-jurisdictional issucs, and the role of the private sector. Additionally, pancl discussions focused on climate change and state coastal erosion management programs. The report has three major sections: an overvicw prepared by the chairman of the colloquium, issue papers by the individual authors, and pancl discussion papers. The colloquium chairman prepared the overvicw based on a review of the issue papers and on presentations made by the provocatcurs and panelists.

As the papers in this proceedings attest, much is known about the causes, characteristics, and consequences of Great Lakes water level fluctuation. Nevertheless, human activities around the lakes have evolved in a way which exposes many people and structures to a hazard of substantial proportions. There is every indication that the magnitude of this hazard will increase in the ruture.

John J. Boland of The Johns Hopkins University, Baltimore, Maryland chaired this colloquium. The report is available in limited quantity at no cost from the Water Science and Technology Board, 2101 Constitution Avenue, N.W., Washington, D.C. 20418.

\section{Letter Report of the Committec on Irrigation-Induced Water} Quality Problems (December 30, 1988)

1988, 3 pp. (W88-8)

This letter report, the third from the Subcommittec on Quality Assurance/Quality Control, stresses the continucd importance of quality assurance and quality control activities to the San Joaquin Valley Drainage Program (SJVDP) even as it winds down its data collection and begins to synthesize information and develop management alternatives. It also urges the SJVDP to create a central repository of information under a single manager. The subcommittee is chaired by Robert R. Meglen, University of Colorado at Denver. The report is available at no cost from the Watcr Science and Technology Board, 2101 Constitution Avenue, N.W., Washington, D.C. 20418.

\section{Letter Report of the Committee on Glen Canyon Environmental Studies}

(December 19, 1988)

1988, 2 p. (W88-7)

A second letter report from this committec was directed to former Secretary of the Interior, Donald P. Hodel on December 19, 1988. The committec felt it was necessary to emphasize its recommendation that the Department of the Interior establish a senior science advisory group and that the chicf scientist or principal investigator be retained through an Interagency Personnel Agrecment to provide long-term continuity for the investigation. After a mecting in October 1988 with Burcau of Reclamation personncl, the 
committce concluded that the execution by the BuRec of its recommendation concerning the establishment of a senior science advisory group needed greater attention. The committee is chaired by G. Richard Marzolf, Murray State University, Kentucky. The report is available at no cost from the Water Science and Technology Board, 2101 Constitution Avenue, N.W., Washington, D.C. 20418.

\section{Letter Report of the Committec on Glen Canyon Environmental Studics}

$$
\text { (July 11, 1988) }
$$

1988, 8 pp. (W88-6)

After the committee's first report, "River and Dam Management" was issued in December 1987, the committee was asked to continue providing scientific advice to the researchers and to review future study plans for the Phasc II Glen Canyon Environmental Studies (GCES) effort. The committce issued its first letter report in July 1988. Recommendations to the Burcau of Rcclamation included cstablishment of a science research advisory group to bc placed at the Department of the Interior level. The committee felt that this was a necessary step in order to avoid past shortcomings in the research and management of the GCES. The function of this advisory group would lie mostly in planning, selection of scientific talent, and help with analysis and interpretation of resear $h$ data.

The committee also lecommended that the Bureau of Reclamation continue monitoring efforts in sediment transport, endangered species populations and trout populations and aggradation and degradation of beaches in the Grand Canyon. An operations analysis was recommended to evaluate both the costs of lost power revenues and the cost of buying additional peak period energy from alternative sources, as well as the potential benefits to other user sectors. A final recommendation was that the Department of the Interior insurc the preservation of the GCES research data and establish a data base management system.

G. Richard Marzolf of Murray State University in Kentucky chaired this committec. The letter report can be obtained at no cost from the Water Science and Technology Board, 2101 Constitution Avenue, N.W., Washington, D.C. 20418.

\section{Water Science and Technology Board Annual Report 1987}

1988, 63 pp. (W88-5)

The fifth annual report of the Water Science and Technology Board (WSTB) discusses the Board's interests, achicvements, and capabilities. It contains an overvicw, descriptions of project activities completed by the Board in 1987, its current program, and plans for the future. The year's highlights included completion of the Board's study of techniques for estimating probabilities of extreme floods, and initiation of several important new 
activities, including a study of ground water modeling approaches and a disciplinary review of the ficld of scientific hydrology. John J. Boland, The Johns Hopkins University, chaired the Board through 1987. The report is available from the Water Science and Technology Board, 2101 Constitution Avenuc, N.W., Washington, D.C. 20418.

\section{Letter Report of the Committee on U.S.G.S. Water Resources Research} (August 1,1988 )

1988, 3 pp. (W88-4)

This report is relevant to and supplements reports W85-5 and W87-5 and concerns funding for and reauthorization of the Water Resources Rescarch Act of 1984 , P.L. $98-242$ which enables the extramural institutes and grants programs administered by the U.S. Geological Survey. The report generally speaks in strong support of these important programs and, following recommendation of their continuation, discusses issues such as research focus, program cost matching, cooperation among institutes, and others. The committec chair was Betty $\mathrm{H}$. Olson of the University of California, Irvine. The report is available from the Water Science and Technology Board, 2101 Constitution Avenue, N.W., Washington, D.C. 20418.

\section{Hazardous Waste Site Management: Water Quality Issues}

1988,224 pp. (W88-3)

The definition of clcanup levels is one of the most controversial and difficult decisions facing policymakers and regulatory agencics responsible for remediating contamination at hazardous waste sites. This report, a collection of papers from a colloquium sponsored by the WSTB, discusses ground and surface water cleanup levels at hazardous waste sites and evaluates whether the scientific, technical, and regulatory methods currently used for setting clcanup levels are adequate. It addresses current methods used by regulatory agencics and the U.S. Department of Defense to establish water quality cleanup lcvels, and provides insight from representatives of water utilitics, industry, regulatory agencies and citizens groups. The report also revicws the use of models and other methods for estimating health risks at hazardous waste sites, and looks at the roles of hydrogeology, engineering, risk assessment, and toxicology, and regulatory strategies in hazardous waste site management.

Michael Kavanaugh, James M. Montgomery Consulting Engincers, chaired the colloquium. The report is available for $\$ 24.50$ from the National Academy Press, 2101 Constitution Avenue, N.W., Washington, D.C. 20418.

\section{Estimating Probabilities of Extreme Floods: Methods and Recommended Research}

1988, 144 pp. (W88-2)

Estimating the probabilitics of extreme floods is a challenging problem with 
important implications in long-term planning and enginecring. Records going back longer than 100 years are uncommon. Thus, predictive techniques mustrely on extrapolation, hydrometcorological modeling, palcollood data, and other statistical procedures.

Estimating Probabilities of Extreme Floods is a scientific examination of a varicty of techniques available for characterizing very rare floods. The authors conclude that opportunities exist to improve the practice and science of rare flood hydrology, and they provide a general approach to flood cstimation that incorporates the best aspects of existing methods. They also makc suggestions for further rescarch to improve our capability to cstimatc extreme floods.

This report provides both a gencral overview and looks in detail at statistical and runoff model techniques. It covers uncertainty analysis, such as the determination of standard crrors and combining crrors into net uncertainty statements, and various statistical analyses, use of rainfall-runoff models, and data needs and avalability. The authors hope the techniques described will aid in the implementation of more sophisticated applications of risk-based decisionmaking in water management. The study committec was chaired by Jared L. Cohon, The Johns Hopkins University. The report is available for $\$ 15.95$ from the National Academy Press, 2101 Constitution Avenue, N.W., Washington, D.C. 20418.

River and Dam Management:

A Revicw of the Bureau of Reclamation's Glen Canyon Environmental Studies

1988,203 pp. (W88-1)

Glen Canyon Dam is one of several high-head, multipurpose storage projects in the Colorado River system and over the years a number of issues have been raised concerning its impacts on the environmental resources of the Grand Canyon. Thus the Bureau of Reclamation conducted a series of approximately 30 studies to evaluate the relationships between dam operations and the natural resources of the Grand Canyon. These analyses, it was hoped, would lead to improvements in reservoir operating policies.

This WSTB report provides recommendations to the Department of the Interior (DOI) concerning the performance and results of these Glen Canyon Environmental Studies (GCES). It reviews the Burcau of Reclamation's planning and management of this project; the integration of the GCES results into a decisionmaking report; and the utility of the GCES results for management of the Colorado River, the Grand Canyon, and the operations of the Glen Canyon Dam.

During its 18-month review of the GCES, the committec found that the Burcau of Reclamation paid insufficient attention to carly planning and careful articulation of GCES objectives; gave inadequate consideration to management options; was uncertain in its ability to convert rescarch results into management options; and failed to identify the rationale for assigning values 10 downstream resources so management goals could be set. Although the Bureau 
of Reclamation's final repori recommends several options, the NRC committec belicves that only those calling for additional work are justified.

The committee's findings and recommendations provide advice to the Department of the Interior rot only on specific components of the GCES but also for the design and concluct of similar environmental studies in the future. Although the eommittec does not believe that the Bureau of Reclamation can make any long-term decisions concerning the management of Glen Canye a Dam based on the GCES, the studies have yielded excellent information about the Colorado River. The study ccmmittee was chaired by G. Richard Marzolf, Kansas State University. Tine report is available in limited quantities from the Water Science and Technology Board, 2101 Constitution Avenue, N.W., Washington, D.C. 20418.

\section{Letter Report of the Committee on Irrigation-Induced Water Quality Problems (July 28, 1987)}

1987,3 pp. (W87-7)

This letter report is the fourth issued by the Committee on Irrigation-Induced Water Quality Problems (CIIWQP) in its efforts to provide continuing advice to the San Joaquin Valley Drainage Program (SJVDP). In this review of the SJVDP's efforts to date, the committee saw some signs of progress, including the program's effort to better define goals and objectives; initial steps taken to consider economic, legal, and institutional factors; and the establishment of a Citizens Advisory Committee. However, the committec also highlighted some important shortcomings: they recommended that the SJVDP review its research schedule and the scope of the intended projects and add an experienced rescarch biologist and a Quality Assurance/Quality Control inanager to its staff.

The committec believes the SJVDP gives inadequate attention to comprchensive integrated planning and stressed that they must consider all the options available to solve the valle'y's drainage problems, even those that are politically unplatable. They also encouraged the Department of the Interior, which is responsible for a West-wide effort to study similar problems, to begin developing policy on how to mitigate the degradation and loss of habitat resulting from contaminated irrigation drainage. The study committee chairman is Jan van Schilfgaarde, USDA-ARS, Fort Collins, Colorado. The report is available from the Water Science and Technology Board, 2101 Constitution Avenue, N.W., Washington, D.C. 20418.

\section{Letter Report of the Committee on Irrigation-Induced Water Quality Problems (July 28, 1987)}

1987, 7 pp. (W87-6)

This is the first letter report issued by the Subcommittee on Economics and Policy of the CIIWQP. Overall, the subcommittee was encouraged that the San Joaquin Valley Drainage Program (SJVDP) had begun to consider cconomic, 
social, legal, and institutional issues in their evaluation of alternative solutions. However, they reminded the SJVDP that the interactions between human activities and the natural environment cannot be ignored and that technology must be seen in light of evolving social and economic systems.

The subcommittce advised the SJVDP that certain topics should be addressed in more detail, including: develop an analytical methodology for identifying the diverse and of ten conflicting environmental and economic considerations involved; examine the equity issues raised by alternative solutions; and broadly evaluate the general public policy issues involved in the alternatives being investigated. The subcommittee also stressed the importance of addressing legal issues. The subcommittec was pleased to see a Citizens Advisory Committee established because public participation can be an effective process for developing a range of options as well as for building public confidence in the decision-making process. The study committec chairman is Jan van Schilfgaarde, USDA-ARS; the subcommittec chairman is Margrict Caswell, University of California-Santa Barbara. The report is available from the Water Suience and Technology Board, 2101 Constitution Avenue, N.W., Washington, D.C. 20418.

\section{Letter Report of the Committee on U.S.G.S. Water Resources Research}

$$
\text { (July 13, 1987) }
$$

1987, 2 pp. (W87-5)

This report supplements report W85-5, issued by the U.S.G.S. Water Resources Research Committec, November 26, 1985. It provides the Committee's current assessment of the Section 105 cxtramural research grants program focus and minor comments intended to improve focus in the Geulogical Survey's program announcement for fiscal year 1988. The committee chairman was Betty H. Olson of the University of California, Irvine. The report is available from the Water Science and Technology Board, 2101 Constitution Avenue, N.W., Washington, D.C. 20418.

\section{Water Science and Technology Board Annual Report 1986}

1987,60 pp. (W87-4)

The fourth annual report of the Water Science and Technology Board (WSTB) discusses the Board's interests, achicvements, and capabilitics. It contains an overview, descriptions of project activitics completed by the Board in 1986, its current program, and plans for the future. The year's highlights included an assessment of environmental studies of the Glen Canyon Dam; a study of techniques for estimating probabilities of extreme floods; the third WSTB colloquium, which debated hazardous waste sitc management and water quality issues; and the continuing efforts of the U.S.G.S. Water Resources Research Committee. In the future, the WSTB plans an assessment of the 
$-54-$

hydrologic sciences, a water markcting study, and a study dealing with the transport and environmental late of contaminants in ground water (see Chapter 4). John J. Boland, The Johns Hopkins University, was WSTB chairman. The report is available in limited supply from the Water Science and Technology Board, 2101 cunstitution Avenue, N.W., Washington, D.C. 20418.

\section{Letter Report of the Committce on Irrigation-Induced Water Quality Problems (March 30, 1987)}

1987, 3 pp. (W87-3)

This is the second letter report issued by the Subcommittee on Quality Assurance and Quality Control (QA/QC) of the CIIWQP. The three-page letter report to the San Joaquin Valley Drainage Program (SJVDP) strongly recommends that the SJVDP acquire a knowledgcable and experienced $Q A / Q C$ manager as soon as possible; the manager should be autonomous from the participating federal and state agencics and answerable only to the SJVDP manager. Another key recommendation is that data management must be performed in a manner that ensures useful information is not lost due to stringent criteria for entry in the data base. The subcommittec was also concerned that the QC protocol for plant tissue appeared to lack the rigor of other protocols (water, soil, sediment, and animal tissue) described by SJVDP staff. The study committec chairman is Jan van Schilfgaarde of the Agricultural Rescarch Scrvice; the subcommittec chairman is Robert R. Meglen, University of Colorado. The report is available from the Water Science and Technology Board, 2101 Constitution Avenue, N.W., Washington, D.C. 20418.

\section{Letter Report of the Committec on Irrigation-Induced Water} Quality Problems (February 17, 1987)

1987, I p. (W87-2)

This is a onc-page supplernent to the first letter report of the Subcommittce on Public Health (dated Junc 9, 1986). The supplement recommends that as the San Joaquin Vallcy Drainage Program evaluates the feasibility and desirability of potential actions to resolve agricultural drainage problems in the San Joaquin Valley it should cxplicitly address the public health concerns that might be raised by such actions. The study committec chairman is Jan van Schilfgarde of the Agricultural Research Service; the subcommittec chairman is Edwin $\mathrm{H}$. Clark of The Conservation Foundation. The report is available from the Water Science and Technology Board, 2101 Constitution Avenue, N.W., Washington, D.C. 20418. 


\section{National Water Quality Monitoring and Assessment}

1987,108 pp. $(W 87-1)$

This is a report on the second WSTB colloquium, held on May 20, 1986 in Reston, Virginia, which discussed the need for a national water quality monitoring and assessment program for the United States. Although the participants were far from unanimous, they concluded that a national water quality monitoring and assessment program, in some form and at some level of effort, is warranted in order to improve the comprehensiveness and reliability of the information available for decisionmaking.

Participants cited numerous areas where a national program might bring improvements, including:

- better understanding of the general quality of the nation's water resources;

- better understanding of water quality trends, specifically changes showing improvement or worsening;

- better understanding of the extent, nature, and causes of water pollution, which would lead to ways to protect human health and the environment;

- improved ability to set standards and assure compliance with regulations;

- improved ability to develop water quality control technology;

- better quality assurance/quality control efforts to ensure greater consistency, compatibility, and reliability of data collection;

- improved data base management and information exchange;

- increased understanding of aquatic phenomena; and,

- better predictive capability.

The colloquium report concludes by stressing that a well planned, reliable water quality monitoring and assessment program necds to be an integral part of any acceptable water resource management strategy. The colloquium chairman was Richard S. Engelbrecht of the University of Illinois. This report is available in limited supply from the WSTB office or the National Technical Information Service, 5285 Port Royal Road, Springficld, VA 22161. NTIS Accession Number: PB 87 157467. Cost: $\$ 18.95$.

\section{A Revicw of the U.S. Army Construction Enginecring Research Laboratory Program for Recycling and Reuse of a Laundry and Shower Wastewater}

1986, 104 pp. (W86-8)

The objective of this study was to evaluate the U.S. Army's Construction Enginecring Research Laboratory (CERL) program on recycling and rcuse of ficld laundry and shower wastewater. The study looks at technical and scientific merit, and recommends additional research needs necessary to achicve the goals of the program. 
In general, the committee found that the CERL studies paid the greatest attention to the technical feasibility of treatment systems, with only limited attention to the water-quality constituents and health concerns. The committee recommended that CERL proceed with its program on laundry/laundry recycling and reuse, bui with some additional testing. The committee concluded that more research on shower wastewater recycling and reuse was essential before CERL implements this program. Specifically, two major routes of exposure should be addressed: inhalation and topical contact. Because of the importance of the inhalation route, the committee recommended additional modeling work for any chemical that appears to be present at sufficient concentrations in the recycled wastewater. Explicit consideration is necessary of the concentration of chlorine and its by-products in air in the laundry room or shower.

The chairman of the committee was Richard S. Engelbrecht, University of Illinois at Urbana-Champaign, Illinois. The report is listed with the National Technical Information Service, 5285 Port Royal Road, Springfield, VA 22161. NTIS Accession Number: PB 87151726.

\section{Letter Report of the Committee on Irrigation-Induced Water Quality Problems (September 5, 1986)}

1986, 2 pp. (W86-7)

This is the third letter report issued by the Committee on Irrigation-Induced Water Quality Problems reviewing research and related programs addressing the agricultural drainage problems in the San Joaquin Valley, California. The letter report recommends that the U.S. Bureau of Reclamation assess a proposal for the cleanup of Kesterson Reservoir made by the Lawrence Berkeley Laboratory (LBL) of the University of California. The LBL proposal hypothesizes that maintaining flooded conditions at Kesterson Reservoir using low-selenium water will create an anaerobic environment in the pond sediments. It is believed that an anaerobic environment would create conditions where selenium is immobilized in a reduced form and, thus, unavailable to biologicaliy cycle in the environment. The committee recommends that basic studies of the biological cycling of selenium in saline, alkaline aquatic ecosystems be given high priority. They recommend that a thorough monitoring system be established to assess the impacts of this management approach on plants, animals, sediments, and water. The study committee chairman is Jan van Schilfgaarde, USDA-ARS, Fort Collins, Colorado. The report is available from the Water Science and Technology Board, 2101 Constitution Avenue, N.W., Washington, D.C. 20418.

Letter Report of the Committee on Irrigation-Induced Water Quality Problems (July 8, 1986)

1986, 6 pp. (W86-6)

This is the first letter report issued by the Subcommittec on Quality 
Assurance and Quality Control of the CIIWQP reviewing a draft quality assurance plan for the San Joaquin Valley Drainage Program (SJVDP). The letter report is critical of the plan and provides many suggestions to improve the document. Among the areas highlighted by the subcommittec are: (1) quality assurance policy and management; (2) data quality objectives and sampling procedures; (3) analytical procedures; (4) data reduction, validation, and reporting; and, (5) performance and system audits. The subcommittee states that a well designed $Q A$ plan can be effective in accomplishing a coordinated program that ensures the overall objectives of the SJVDP while preserving the independence and flexibility that the individual participating agencies require. The study committec chairman is Jan van Schilfgaarde, USDA-ARS; the subcommittee chairman is Robert R. Meglen, University of Colorado. The report is available from the Water Science and Technology Board, 2101 Constitution Avenue, N.W., Washington, D.C. 20418.

\section{Letter Report of the Committec on Irrigation-Induced Water Quality Problems (June 12, 1986)}

1986, 4 pp. (W86-5)

This is the first letter report issued by the Subcommittec on Public Health of the CIIWQP revicwing the research proposed by the Ad Hoc Committee on Public Health of the San Joaquin Vallcy Drainage Program (SJVDP). Gencrally, the subcommittee was impressed with the breadth and quality of the proposed studics, but some deficiencies were identified. The subcommittees' comments fall into five categorics: (1) the need for a more coherent conceptual approach; (2) identification of hazards; (3) exposurc assessment; (4) integration of public health delivery services; and (5) the establishment of a public health subcommittee within the SJVDP. The study committec chairman is Jan van Schilfgaarde of the Agricultural Rescarch Service; the subcommittee chairman is Edwin H. Clark of the Conservation Foundation. The report is available from the Water Science and Technology Board, 2101 Constitution Avenue, N.W., Washington, D.C. 20418.

\section{Ground Water Quality Protection: State and Local Strategies}

1986, 309 pp. (W86-4)

This report reviews ground water protection strategies in ten states and three local areas of the United States. A study committce initiated its effort in November 1984 after the U.S. Environmental Protection Agency requested a review of state and local ground water programs, focusing on prevention of ground water contamination. The revicw considered these programs with respect to their scientific bases, performance over time, administrative requirements, and their legal and cconomic rrameworks. The states and local areas reviewed werc: Arizona, California, Massachusetts and Cape Cod, 
Colorado, Connecticut, Florida and Dade County, Kansas, New York, Long Island, New Jersey, and Wisconsin.

The committee found that no program had all the elements necessary to a comprehensive ground water protection program: (1) clearly defined goals, objectives, scope, and prioritics; (2) an adequate information base to allow proper definition of the resource and the problems; (3) a sound technical basis; (4) elimination or reduction of the sources of ground water contamination; (5) intergovernmental and interagency linkages; (6) cffective implementation and adcquate funding; (7) studics on the cconomic, social, political and environmental impacts of ground water protection; and (8) public support and responsiveness.

The report emphasizes the need to climinate or reduce the sources of ground water contamination and recommends ways to deal with both hazardous and nonhazardous waste. Other recommendations focus on preventing pesticide contamination; the need for state and local programs to obtain hydrogeological information; the use of a classification system to identify critical areas and resources for special protection; water quality standards and EPA's proposed RMCL's and MCL's for all inorganic and organic chemical compounds commonly found in ground water; land use controls; adequate legal authority and funding for ground water protection programs; and political mobilization and public participation in support of ground water protection programs.

The report states that the essence of prevention is anticipation, planning, assessing, and preventive action. These preventive efforts anticipate adverse effects from chemical and land use practices and the disposal of waste. The emphasis is on prevention of pollutants at the source. The study committee chairman was Jerome B. Gilbert, East Bay Municipal Utility District, Oakland, California. The report is available from the National Academy Press, 2101 Constitution Avenue, N.W., Washington, D.C. 20418 . List price: $\$ 24.50$.

\section{Drought Management and Its Impact on Public Water Systems}

1986,127 pp. (W86-3)

This report--the first in the WSTB's scries of colloquia to focus attention on emerging issues in water science, technology, and policy--addresses drought management and its impact on public water systems. The colloquium was held September 5, 1985 in Boulder, Colorado.

The report concludes that there is substantial need for continucd research on drought and its impacts. Key rescarch topics include the causes of drought, developing effective drought alert mechanisms, probability analysis of drought, quantifying of the conscquences of system failure during drought, and id ntifing of the institutional environment necessary for successful implementation of drought management plans. According to the report, the key to adequate drought management in public water systems lies in predrought preparation. The colloquium chairman was Robert L. Smith of the University of Kansas. The report is available from the National Academy Press, 2101 Constitution Avenue, N.W., Washington, D.C. 20418. List pricc: $\$ 7.50$. 


\section{Water Science and Technology Board Annual Report 1985}

1986, 54 pp. (W86-2)

This is the third annual report published by the WSTB since its creation in 1982. The report contains an overview of the Board's activities, including the introduction of a new colloquium series on emerging issues in water science, technology, and policy; descriptions of project activities; the overview of and conclusions from the Board's first colloquium on Drought Management and Its Impact on Public Water Systems; and planned projects. Research needs in water science and technology are highlighted. Lists of program participants, the Board's Terms of Reference, abstracts of reports published by the Board since 1982, and a list of meetings held by the Board and its committees during 1985 are included. The WSTB chairman was John J. Boland of The Johns Hopkins University. The report is available from the Water Science and Technology Board, 2101 Constitution Avenue, N.W., Washington, D.C. 20418.

\section{Letter Report of the Committee on Irrigation-Induced Water Quality Problems (April 2, 1986)}

1986, 3 pp. (W86-1)

This is the second letter report from the Committee on Irrigation-Induced Water Quality Problems and it responded to briefings provided by the University of California research program about irrigation drainage problems in the San Joaquin Valley. The letter report notes that a number of recommendations made in the committee's first letter report (October 10, 1985) have been enacted by the San Joaquin Valley Drainage Program (SJVDP), but it urges that other recommendations (such as development of a strong public participation program; full consideration of economic, institutional, and legal factors; investigation of public health concerns; and development of a quality assurance/quality control program and a data management program) be implemented as soon as possible.

The committee praises the research being conducted to address on-farm water and salinity management, transport processes, and trace element chemistry. However, the committee believes the University of California researchers should be more fully integrated into the overall SJVDP research program. Areas of research requiring attention include public health concerns; economic evaluations of potential alternative solutions, which include social and private impacts; and the long-term impacts on ecosystems. The committee cmphasizes that the environmental consequences of various technological alternatives are not being adequately addressed and suggests that the resources available through the university be better used to achieve that end. The study committce chairman was William H. Allaway of Ithaca, New York. The report is available from the Water Science and Technology Board, 2101 Constitution Avenue, N.W., Washington, D.C. 20418. 
The Great Lakes Water Quality Agreement: An Evolving Instrument for Ecosystem Management

1985, 224 pp. (W85-6)

This report is a revicw of the 1978 Great Lakes Water Quality Agreemen, between the United States and Canada, beginning in 1984 and ending with the issuance of a final report from a binational committee of the Royal Society of Canada and the National Research Council in December 1985. The report covers four major areas concerning the Great Lakes and the agreement: enrichment, toxic contaminants, institutional arrangements and the ecosystem approach, and sustainable development.

The committee found that major progress has been achieved in reducing levels of phosphates and several pollutants in the Great Lakes. However, there remains an "urgency to achieve a reduction of toxic pollutants in the Great Lakes and thereby reduce the risks to the human population using the resources of the basin." One major finding is that people living in the Great Lakes region are exposed to appreciably more toxic chemicals through contaminated drinking water and food products than other similar populations in North America.

Both the 1972 and 1978 Great Lakes Water Quality Agreements are widely recognized as among the world's pioncering international instruments designed to foster intergovernmental coopcration to correct pollution in a large river basin. The committec concluded that the two governments should cortinue and strengthen the 1978 Agrecment. The joint institutions created in the 1978 Agreement, the Water Quality Board and the Science Advisory Board, have proven to be effective means for advancing dialogue between the parties to the agreement (United States and Canada) and among the various states and provinces on technical questions, programs, and expenditures.

To improve accountability in carrying out the agreement, the committee suggested that the U.S. and Canadian governments publish a report every two years on the progress achieved, and that bilateral meetings be held regularly between senior officials to discuss any problems. In addition, the committee belicves there needs to be a clearcr delineation of the responsibilities of the various institutions in managing Great Lakes water quality. Such clarification would improve the functioning of the various institutions as well as provide greater accountability for their actions. The committec also wants to see Great Lakes water quality managed more from an ecosystem approach. This means that Great Lakes water quality related programs and policies, and the institutions that implement them, should be guided by the basic ecosystem goals set forth in the 1978 Agreement to "restore and maintain the integrity of the waters of the Great Lakes basin ccosystem."

The committec's rinal recommendation was that the parties to the Agreement should plan a binational conference on the Great Lakes and establish an action plan to be acted on at the conference, preferably before the end of the decade. In general, the committec found that substantial reforms are still needed in the Great Lakes basin, far beyond the programs specificd in the 1972 and 1978 Agrecments, and that now is an appropriate 
time to face the challenge. The study committee co-chairmen were Orie Loucks of the Holcomb Research Institute, and Henry Regicr of the University of Toronto. The report is available from the National Technical Information Service, 5285 Port Royal Road, Springfield, VA 22161. NTIS Accession Number: PB 87-186292. Cost: \$24.95.

\section{Letter Report of the Committec on U.S.G.S. Water Resources Research}

(November 26, 1985)

1985,9 pp. (W85-5)

This report recommends a focus for the research grants program administered by the U.S. Gcological Survey and authorized by section 105 of the Water Resources Research Act of 1984. The report reviews the scope of water resources research and previous "prioritization" and rescarch review efforts. It then discusses the committec's criteria and delineates two general areas of research in need of attention and decmed appropriate for the section 105 grants program: (1) science and technology of water quality management, including scientific understanding of hazardous substances in water, applications of biotechnology to water resources, and engineering and technology related to chemical and biological applications for water resources systems; and (2) water resources institutional issues, including water allocation, design of regional water systems, and incentives for regional cooperation. The committee chairman was James J. Morgan of the California Institute of Technology. The report is available from the Water Science and Technology Board, 2101 Constitution Avenuc, N.W., Washington, D.C. 20418.

\section{Letter Report of the Committce on Irrigation-Induced Water Quality Problems (October 10, 1985)}

1985,11 pp. (W85-4)

This report--the first of the Committee on Irrigation-Induced Water Quality Problems--followed several days of briefings about the San Joaquin Valley Drainage Program (SJVDP). The letter report calls for improved coordination of research activitics and overall program management of the SJVDP, and it stressed the need for a program of public participation. Other critical areas of concern included the need for data management and the ongoing interpretation of data to provide fecdback on the overall research program and clarify future research necds; the importance of establishing sound quality assurance/quality control programs in providing useful and defensible data; the need to consider agricultural chemicals in the design of analytical studies; the significance of economic, legal, institutional, and financial constraints and their influence on the range and ultimate selection of alternatives; and the need to thoroughly' consider on-farm management options. The letter report also addresses the rescarch programs proposed by the U.S. Geological Survey, the U.S. Fish and Wildlife Service, and the U.S. Burcau of Reclamation. The 
report is the first in what is expected to be a series providing timely and constructive guidance to the San Joaquin Valley Drainage Program. The committee chairman was William H. Allaway of Ithaca, New York. The report is available from the Water Science and Technology Board, 2101 Constitution Avenue, N.W., Washington, D.C. 20418.

\section{Letter Report of the WSTB Working Group to Review Plans for a} National Water Quality Assessment Program (October 7, 1985)

1985, 3 pp. (W85-3)

This report was written by an ad hoc work group, consisting of Water Science and Technology Board members and members of the Committee on U.S.G.S: Water Resources Research, to react to documents and briefings on the proposed National Water Quality Assessment Program. The report stresses the need for and value of such a program and includes suggestions to improve the design and implementation of the planned program. The workgroup chairman was Walter R. Lynn of Cornell University. The letter report is available from the Water Science and Technology Board, 2101 Constitution Avenue, N.W., Washington, D.C. 20418.

\section{WSTB Review of U.S. Department of Energy (DOE) Report "Transport of Energy-Related Organic Compounds and Mixtures in Subsurface Environments"}

1985, 6 pp. (W85-2)

In response to a request from the U.S. Department of Energy (DOE) in October 1984, an ad hoc subcommittee of the WSTB reviewed a DOE report titled "Transport of Energy-Related Organic Compounds and Mixtures in Subsurface Environments" (November 1984). The DOE document was a "concept paper" describing a research plan to be adopted by the department. The WSTB subcommittce's task was to provide a scientific overview of the proposed rescarch and suggest ways to improve the scientific content of the plan. The subcommittec commented on the need for and importance of the research, the proposed timetable, and the need for controlled ficld facilities prior to conducting experiments at natural field sites. The subcommittee chairman was Mary P. Anderson of the University of Wisconsin-Madison. The letter report is available from the Water Science and Technology Board, 2101 Constitution Avenue, N.W., Washington, D.C. 20481.

\section{Water Science and Technology Board Annual Report 1984}

1985,48 pp. (W85-1)

The second annual report from the WSTB summarizes activities completed during 1984 , ongoing activities, and future plans. It includes information on 
board and committee memberships, program organization, issues of concern, and reports published. Highlights include the introduction of several new studies on topics such as groundwater protection; a bi-national review of the Great Lakes Water Quality Agreement; and a water resources research committee to assist the U.S.G.S. and the WSTB with water rescarch-related matters. The board chairman was John J. Boland of The Johns Hopkins University. The report is available from the National Technical Information Service, 5285 Port Royal Road, Springfield, VA 22161. NTIS Accession Number: PB 85 204485/AS. Cost: $\$ 10.00$.

\section{Safety of Dams: Flood and Earthquake Criteria}

1985,321 pp. (W84-5)

This report was prepared in 1984 at the request of the Assistant Secretary of Interior for Water and Science and the Assistant Secretary of the Army for Civil Works. The report concerns the levels of safety to be provided at new and existing dams to withstand extreme floods and earthquakes. The report includes a thorough inventory of safety criteria for dams in use in the United States and internationally, especially as related to design for lloods and carthquakes. The report critiques a variety of present practices and recommends alternative safety criteria. Also included are chapters on risk assessment, legal aspects of dam safety, and recommendations for continuing development of hydrologic and earthquake engineering technologies.

The findings and recommendations of the study committee are condensed in an executive summary. Technical appendixcs provide discussions on probable maximum precipitation estimates, statistical hydrology, and risk assessment. A glossary of technical terms is also included. The report emphasizes that a principal objective in dam safety evaluations should be to strike a balance among considerations such as project bencfits, construction costs, social costs, and public safety, including the possible consequences of dam failure due to major earthquakes and floods. The study committce chairman was Gcorge W. Housncr of the California Institute of Technology. The report is available from the National Academy Press, 2101 Constitutation Avenue, N.W., Washington, D.C. 20418. List price: $\$ 16.50$.

\section{Review of the Great Lakes Water Quality Agrecment: Working Papers and Discussion}

1984,174 pp. (W84-4)

The William H. Donner Foundation, in consultation with the staff of the International Joint Commission (IJC), asked the WSTB to study the Great Lakes Water Quality Agrecment in two phases. The first phase, the subject of these procecdings, consisted of a conference to define the details of a major review study. Conference participants were asked to identify those scientific, technical, and institutional issues upon which an in-depth study, in its second 
phase, should focus. This report contains live formal papers, the discussion that followed each presentation, and a final summary chapter prepared by the Conference Advisory Panel. These discussions are to be used as background information for the phase II effort. The conference chairman was Orie Loucks of the Holcomb Research Institute. The report is available from the National Technical Information Service, 5285 Port Royal Road, Springficld, VA 22161. NTIS Accession Number: PB 85-110807. Cost: $\$ 17.50$.

\section{Water Science and Technology Board Annual Report 1983}

\section{4,39 pp. (W84-3)}

This was the first annual report published by the WSTB. The report includes an introduction describing the types of issues handled by the WSTB and its committees; a description of the WSTB's place within the NRC structure; project activities completed in 1983; a description of current and planned projects; and a list of rescarch needs in water science and technology as envisioned by WSTB members. Appendixes also list program participants, the WSTB's Terms of Reference, and brief descriptions of all published reports. The board chairman was Walter R. Lynn of Cornell University. The report is available from the National Technical Information Service, 5285 Port Royal Road, Springfield, VA 22161. NTIS Accession number: PB 84-216571. Cost: $\$ 8.50$.

\section{Water for the Future of the Nation's Capital Area- 1984}

1984, 71 pp. (W84-2)

This report is the culmination of a continuing review by the National Research Council (NRC) of the U.S. Army Corps of Engineers Metropolitan Washington Area Water Supply Study, a study which was initiated in 1977 and compleied in 1983.

The committee was charged with revicwing the Corps methods investigating the future water resources needs of the metropolitan Washington area and to report the scientific bases for the conclusions reached. The committee issued five letter reports, one interim report, and one final report to the Corps within a seven-year period.

In its final report, the committee acknowledges and commends the Corps for certain achievements, such as: (1) developing systems management (nonstructural) solutions to problems relative to the metropolitan Washington arca future water supply needs, (2) detcrmining and assessing future water demands by the use of improved modeling, (3) developing a wide range of alternative methods of mecting future water resources needs of the metropolitan Washington area, (4) involving the citizens of the metropolitan Washington area in devcloping design criteria and making recommendations for future actions, and (5) collecting and collating current and historical data to use in the analysis of the metropolitan Washington arca study. 
However, the committec also highlighted several flaws in the Corps study. These flaws concern: (1) the uncertain reliability of institutional arrangements, (2) the nonpreservation of reservoir sites, and (3) the lack of scientific attention in assessing the drinking water quality available to the metropolitan Washington area. The study committec chairmen were Danicl A. Okun of the University of North Carolina, and Walter R. Lynn of Cornell University. The report is available from the Water Science and Technology Board, 2101 Constitution Avenue, N.W., Washington, D.C. 20418, and the National Technical Information Service, 5285 Port Royal Road, Springfield, VA 22161. NTIS Accession number: PB 84-195585. Cost: $\$ 11.50$.

\section{The Potomac Estuary Experimental Water Treatment Plant}

1984,135 pp. (W84-1)

This report is the culmination of an eight-ycar revicw by the NRC of the U.S. Army Corps of Engineers study to determine the feasibility of using the Potomac estuary waters as a source of water supply to the metropolitan Washington area. In this connection, a two-ycar pilot plant project was authorized involving the construction, opcration, and evaluation of a small water treatment plant. The NRC committce was requested to provide a review and written report commenting on the scientific bases for the conclusions reached by the Corps from this study. The NRC committec had been reviewing the Corps study since 1976 and issued four letter reports, a panel report, and a final report to the Corps within an eight-ycar period.

In its final report the committee commends the Corps study for certain outstanding features, including: (1) detailed comparative cvaluation of the quality of treated estuary water with that of threc major treated water supplies for the metropolitan Washington arca, (2) development of a detailed inorganic and organic chemical characterization of treated estuary water and of local water supplics, (3) development of a data base on microbiological contaminants and toxicological indications, and (4) the demonstrated reliability of advanced treatment processes to provide treated water with relatively consistent quality.

However, the committee also felt that there were important limitations to this study and its conclusions, including: (1) insufficient scientific evidence was provided to adequatcly evaluate the safety to humans from consumption of treated estuary water, (2) potential changes in the quality of cstuary water that might result from biological growth during drought conditions were not adequately addressed, (3) failure to detect viruses in the experimental estuary water treatment plant finished watcrs cannot be accepted as an indication that they are absent, and (4) the cconomic evaluation of a Potomac cstuary water treatment plant was inadequate because it did not provide a comparative cost with other alternatives. The study committce chairman was Perry L. McCarty of Stanford University. The report is available from the Water Science and Technology Board, 2101 Constitution Avenue, N.W., Washington, D.C. 20418 and the National Technical Information Scrvice, 5285 Port Royal Road, Springficld, VA 22161. NTIS Acccssion number: PB 84-195643. Cost: $\$ 16.00$. 
The Lake Erie-Niagara River Ice Boom: Operations and Impacts

1984, 74 pp. (W/83-4)

This report is the result of a request from the International Joint Commission (IJC)--United States and Canada--to the NRC to assist in resolving issues associated with the ice boom located at the entrance to the Niagara River, New York and Ontario. The panel's mission was to address whether the ise boom has a climatic effect in the Buffalo/Fort Eric region, and if so, to determine the magnitude of that effect and what alternative ice control strategy could be used that would have less of a climatic effect.

The pancl found:

1. no cooling to local climates if the boom is removed when there is 250 $\mathrm{mi}^{2}$ of ice on Lake Eric;

2. no monitoring program is required;

3. no benefit of the boom to the region after the beginning of April have been demonstrated;

4. no negative impacts of the ice boom on navigation, erosion and fisheries could be demonstrated with available data; and

5. no feasible alternative exists that would produce effectivencss comparable to the present ice boom.

The study panel chairman was Harry L. Hamilton, Jr. of the State University of New York--Albany. The report is available from the National Technical Information Scrvice, 5285 Port Royal Road, Springfield, VA 22161. NTIS Accession number: PB 84-129709. Cost: \$11.50.

\section{Safety of Existing Dams: Evaluation and Improvement}

1983, 384 pp. (W83-3)

The goal of this report is to enhance dam safety, in particular to provide guidance for achicving improvements in the safety of existing dams within financial constraints. Many dam owners are faced with safety problems of such a nature and extent that they are unable to finance remedial measures. To these owners, as well as to regulatory agencies and others concerned with the enginecring and surveillance of dams, the report presents suggestions and guidance for assessing and improving the safety of existing dams. The contents of the report is intended to be informational and not to advocate rigid criteria or standards. The repolt also contains a glossary for terms used in relating to dam safety and an index. The study committce chairman was Robert B. Jansen, consulting enginecr. The report is available from the National Academy Press, 2101 Constitution Avenue, N.W., Washington, D.C. 20418. List price: $\$ 19.95$. 
Letter Report: May 31, 1983 to U.S. Department of Interior U.S. Geological Survey and Office of Water Policy

This letter report responds to a U.S.G.S. request for comments on an outline for the proposed National Watcr Summary 1983--Hydrologic Setting of Water-Related Issues. The review was provided in accordance with the WSTB's contract with U.S.G.S. to provide advice and short reports on selected issues. The letter report comments on the need for, expectations, and content of the proposed document. The WSTB endorses the concept of the national water summary as an interim, prototype data base until the needs and contents of a "national assessment" program are more thoroughly reviewed. The board chairman was Walter $R$. Lynn of Cornell University. The report is available from the Water Science and Technology Board, 2101 Constitution Avenue, N.W., Washington, D.C. 20418.

\section{Cooperation in Urban Water Management, Conference Procecdings}

1983,187 pp. (W83-1)

The WSTB held a conference on October 14-15,1982, to assess the barriers to efficient management of urban water supplics, titled "Cooperation in Urban Water Management." A stcering committec invited 30 participants to the conference. The conferees explored and proposed means for overcoming obstacles envisioned by water supply professionals that prevent or assign low priority to solutions to criscs in municipal water supplies. The primary objective of the conference was to decide if a broader and more intense study by the NRC is warranted. A second objective was to provide guidance on research needs, development, and technology transfer regarding municipal water supplies. These proceedings include the speakers' presentations and a summary of the general discussions. The corference was supported by the National Science Foundation, the Environmental Protection Agency, the American Water Works Association Research Foundation, and the National Academy of Sciences. The conference chairman was David 4 . Marks of the Massachusetts Institute of Technology. The report is available from the National Technical Information Service, 5285 Royal Road, Springfield, VA 22161. NTIS Accession number: PB 83-217992. Cost: $\$ 17.50$. 


\section{JANUARY}

$5-6$

$11-12$

$14-16$

$28-29$

$\underline{\text { MARCH }}$

17

$17-18$

$24-25$

\section{APRIL}

$25-26$

$28-30$
Committec on Opportunities in the Hydrologic Sciences, Washington, D.C.

Committce on Watcr Resources Research, Tucson, Arizona

Committec on Ground Water Modeling Assessment, University of Florida, Gainesville

Committee on Irrigation-Induced Water Quality Problems, Tucson, Arizona

Water Science and Technology Board, Chicago

Colloquium on Great Lakes Water Levels:

Shoreline Dilcmmas, Chicago

Glen Canyon Environmental Studies Committee, Tucson, Arizona

Committec on Ground Water Modeling Assessment, Washington, D.C.

Committec on Opportunities in the Hydrologic Sciences, Boulder, Colorado

$-68-$ 


\section{MAY}

5-6

$24-25$

JUNE

2

7

$23-24$

2.4

$\underline{\text { JULY }}$

$25-26$

\section{AUGUST}

$18-19$

\section{SEPTEMBER}

1

9

$29 \cdot 30$
Committec on Irrigation-Induced Water Quality Problems, Washington, D.C.

Committee on Coastal Erosion Zone Management, Washington, D.C.

Committec on U.S.G.S. Water Resources Research, Washington, D.C.

Colloquium V Planning Session: Control Strategies for Aquifer Remediation, Washington, D.C.

Restoration of Aquatic Systems Planning Session, Lakc Tahoc, Nevada

Subcommittces on Economics and Policy, and Systems Analysis, Berkeley, California

Planning/Discussion concerning Planning for Water Supply Emergencies, Washington, D.C.

Committce on Coastal Erosion Zone Management, Beckman Center, Irvine, California

Watcr Science and Technology Board, Beckman Center, Irvinc, California

Workshop on Long-Term Water Quality Monitoring, Reston, Virginia

Oricntation Mecting on National Water Quality Assessment Pilot Program, Reston, Virginia (Chairman/Staff only)

Committce on Coastal Erosion Zone Management, Miami Beach, Florida 
SEPTEMBER (continued)

$29-30$

Committce on Irrigation-Induced Water Quality

Problems, Beckman Center, Irvine, California

\section{OCTOBER}

$6-8$

$13-14$

$24-25$

$26-28$

\section{NOVEMBER}

15

16

30

\section{DECEMBER}

$1-2$

$12-13$
Committce on Opportunitics in the Hydrologic Sciences, Berkeley, California

Committee on Water Resources Rescarch, Beckman Center, Irvine, California

Committec on National Water Quality Assessment Pilot Program, Washington, D.C.

Glen Canyon Environmental Studies Oversight Committce, Page, Arizona

Liaison Representalives of the Committec on Opportunitics in the Hydrologic Sciences, Washington, D.C.

Executive Committec of the Committee on Ground Water Modeling Assessment, Chicago, Illinois

Colloquium Planning Scssion: Ground Water and Soil Contamination Remediation: Are Science and Public Policy Compatible?, Washington, D.C.

Technical Pancl, Coastal Erosion Zone Management Committec, Washington, D.C.

Water Scicnce and Technology Board, Washington, D.C. 

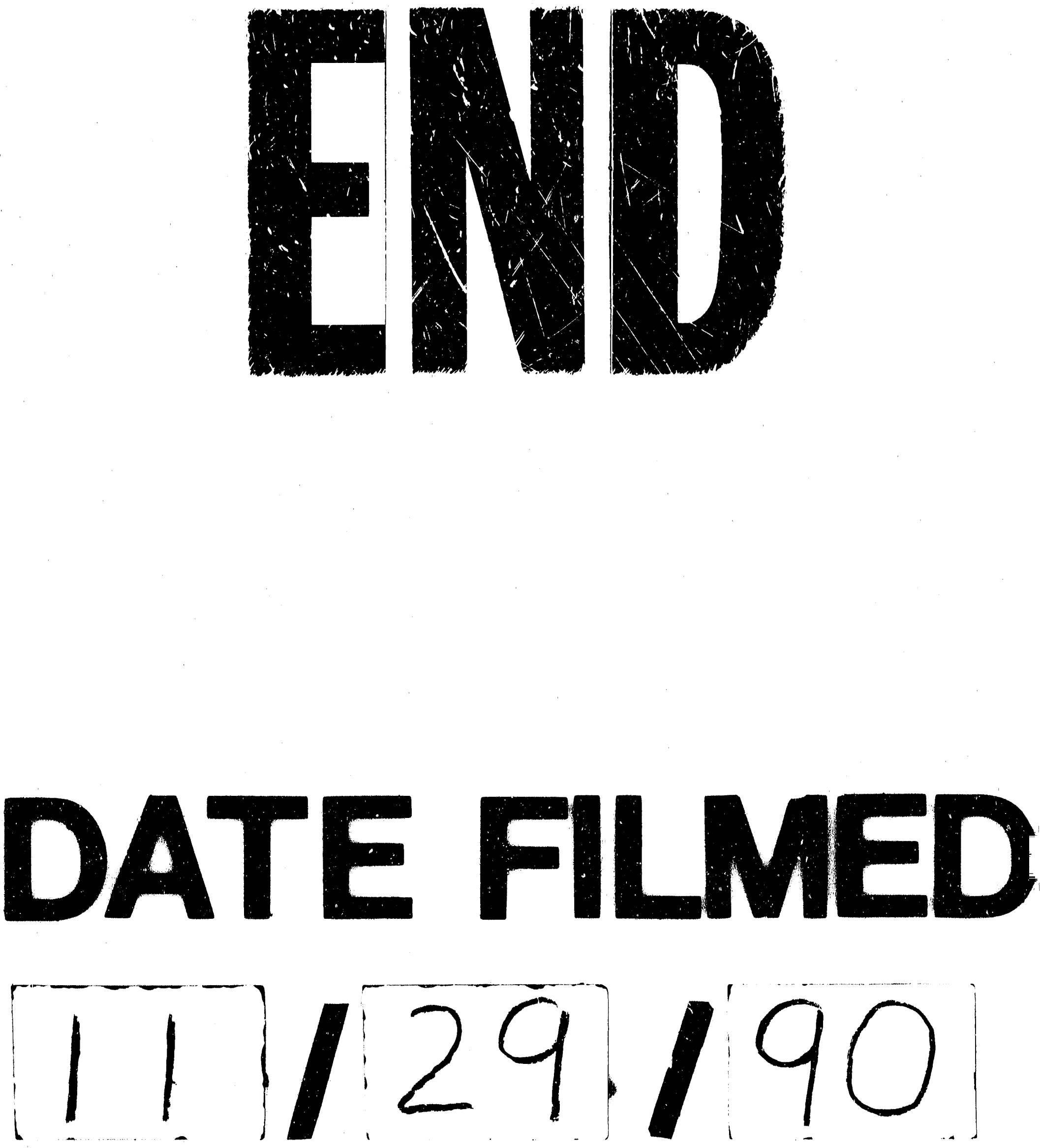
